\title{
University of New Mexico
}

UNM Digital Repository

$12-3-2008$

\section{Modeling Road Erosion in the Upper Torreon Wash, New Mexico}

Krista M. Schultz

Follow this and additional works at: https://digitalrepository.unm.edu/wr_sp

\section{Recommended Citation}

Schultz, Krista M.. "Modeling Road Erosion in the Upper Torreon Wash, New Mexico." (2008). https://digitalrepository.unm.edu/ wr_sp/95

This Technical Report is brought to you for free and open access by the Water Resources at UNM Digital Repository. It has been accepted for inclusion in Water Resources Professional Project Reports by an authorized administrator of UNM Digital Repository. For more information, please contact disc@unm.edu. 


\section{Modeling Road Erosion in The Upper Torreon Wash, New Mexico}

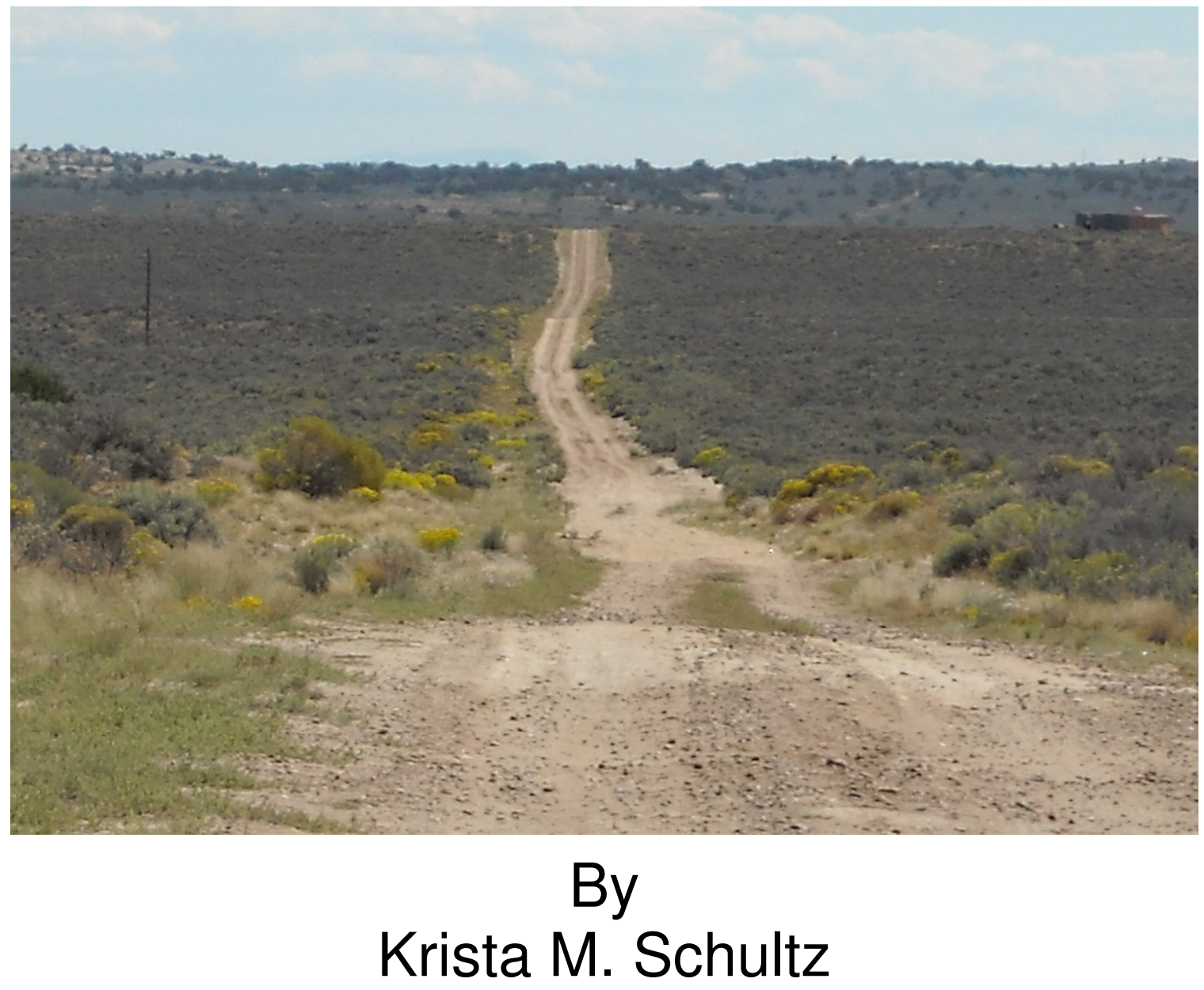

A professional project report submitted in partial fulfillment of the requirements for the degree of Master of Water Resources

Policy/Management Concentration

Water Resources Program

The University of New Mexico

Albuquerque, New Mexico

December 2008 


\section{Committee Approval}

The Master of Water Resources Professional Project Report of Krista M. Schultz, entitled Modeling Road Erosion in The Upper Torreon Wash, New Mexico, is approved by the committee:

Bruce Thomson, Chair

Date

Paul Zandbergen

Date

David Mattern

Date 


\section{Acknowledgments}

I wish to thank my committee chair, Dr. Bruce Thomson, for his encouragement and assistance throughout this process. In addition, I would like to thank Dr.Paul Zandbergen, who clarified methods and complexities, and David Mattern M.S. for initiating the project, providing project direction, and for his on-the-ground support.

I would also like to thank Dawn Chavez, whose assistance with the Geographic Information Systems proved invaluable. Her skills and talents in this area are unmatched, and I appreciate her willingness to share them with me.

I am grateful to the members of the Navajo Nation Ojo Encino Chapter who assisted me in the field while directing my project objectives. Their kindness and advice was greatly appreciated.

Gratitude is extended to Bill Elliot, WEPP Project Leader, and David Hall, IT Specialist, from the USDA Forest Service, Rocky Mountain Research Station. They have provided valuable insight and reprogrammed the WEPP parameters specifically for this analysis.

Lastly, I would like to thank my family for their unconditional support and sacrifices: my husband Jim and daughter Ria, whose inspiration and guidance have made all things possible. 


\section{ABSTRACT}

Accurate prediction of sediment detachment, transport, and delivery from dirt-road networks is an expensive and time-consuming task. The Water Erosion Prediction Project (WEPP) soil erosion model allows users to predict road erosion based on specific characteristics including road length, width, and gradient. The approach can be applied to specific climate conditions, multiple road designs, and unique attribute information. The methodology was applied to roads in the upper Torreon Wash located in northwestern New Mexico. Main roads and access routes within the study area were evaluated to determine the estimated sediment delivery from unpaved roads. This study incorporates results from the WEPP model to determine the impact of erosion on the described area. The analysis was designed to identify areas of intense erosion as well as sediment delivery to stream systems, and included a case study to determine the effects of past remediation efforts. Collected data was stored and organized using geographic information systems to visualize the spatial component, a method that also provided effective data management, analysis, and mapping capabilities within a geographic environment. Remediation work consisted of 110 rolling dips that were installed on roads in the study area. Findings suggested that remediation efforts can reduce road erosion by $48 \%$. Results also showed that, by reducing the sediment loads that stem from neighboring roads, remediation work had a positive impact on nearby streams. Overall, the remediation efforts have been successful at reducing erosion in the study area. 


\section{Table of Contents}

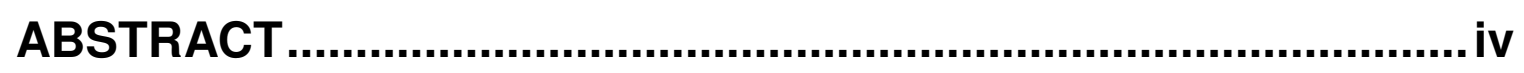

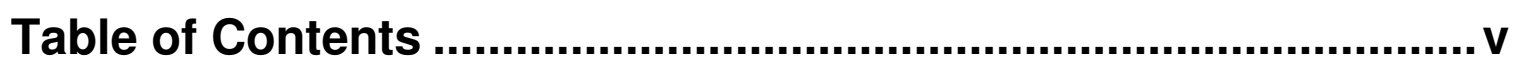

List of Figures.............................................................................. vii

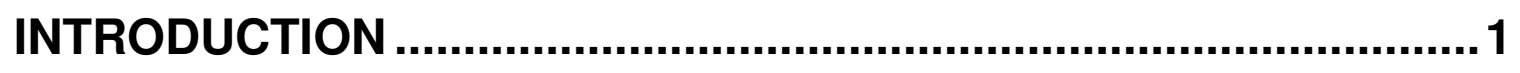

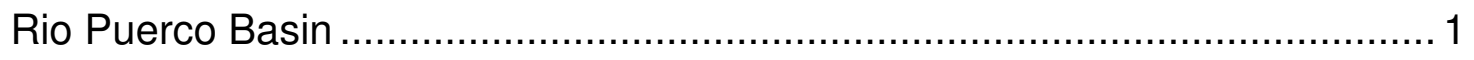

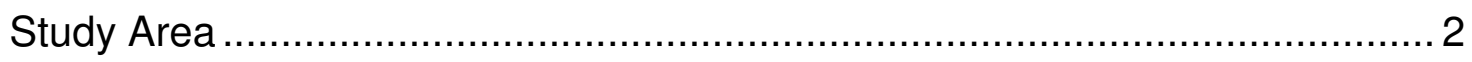

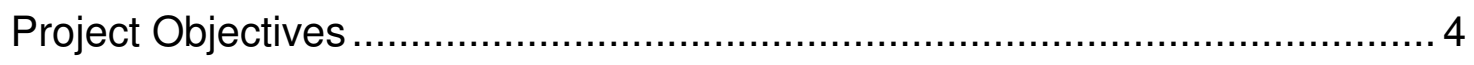

THE WEPP MODEL ................................................................... 5

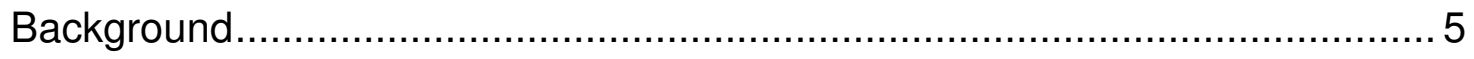

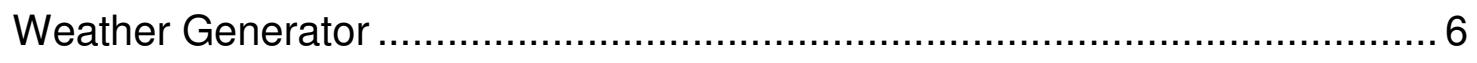

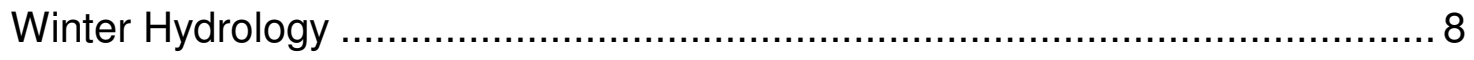

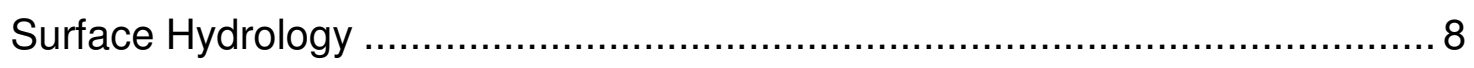

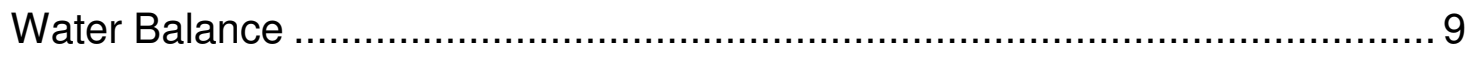

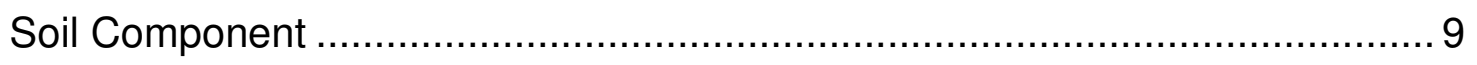

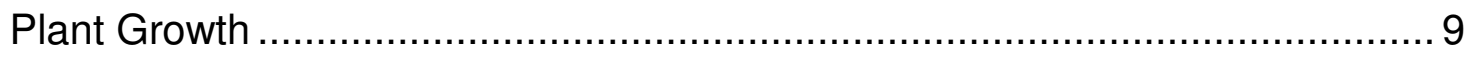

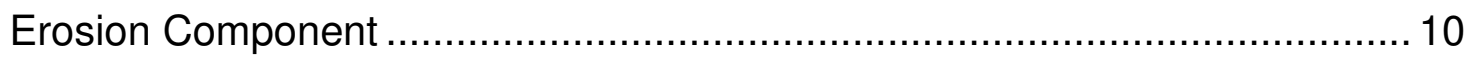

WEPP INPUT PARAMETERS ................................................... 10

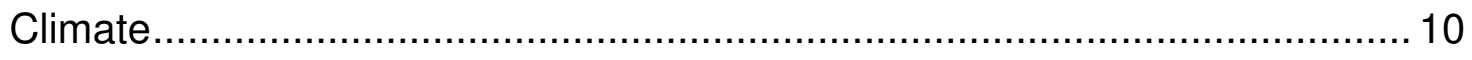

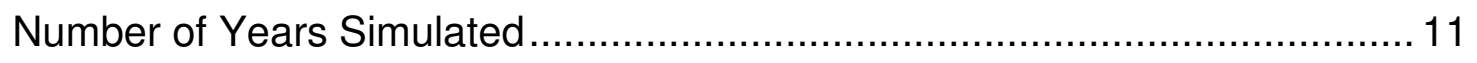

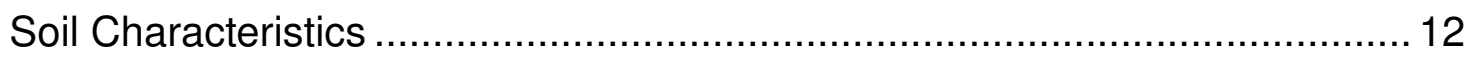




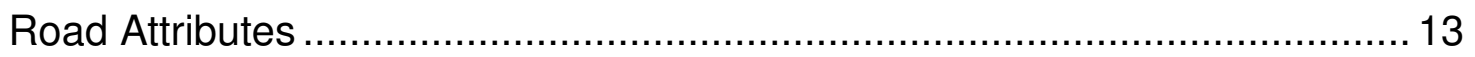

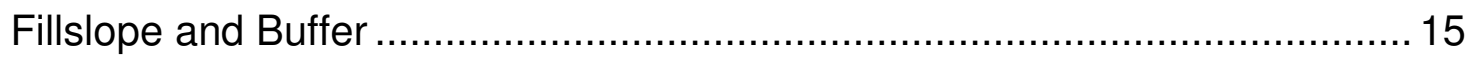

Percent of Rock Fragments .............................................................. 17

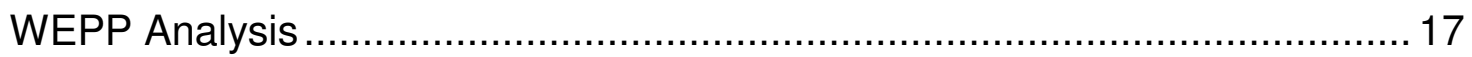

METHODOLOGY ........................................................................ 18

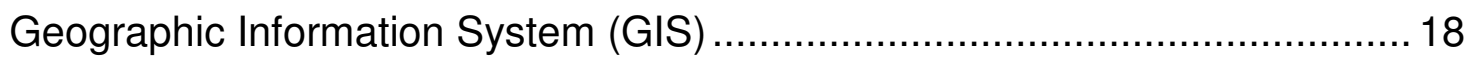

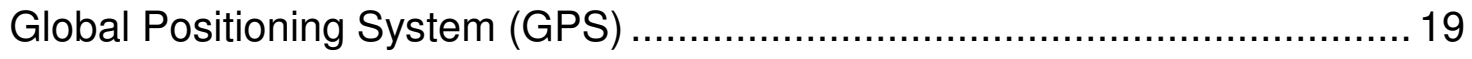

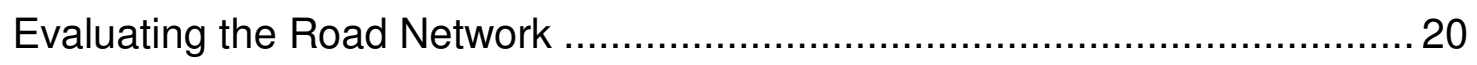

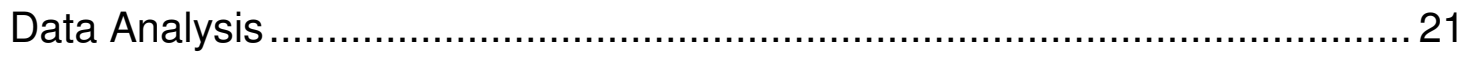

RESULTS................................................................................. 22

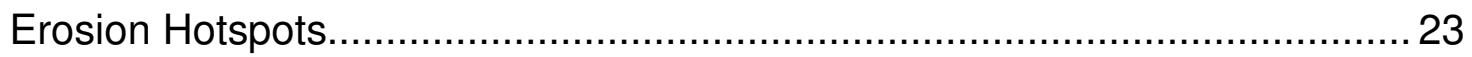

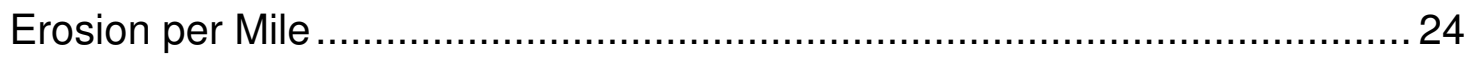

Sediment Deposits to the Stream System ……......................................... 25

Case Study: A Before-and-After Analysis of Mitigation Efforts.......................29

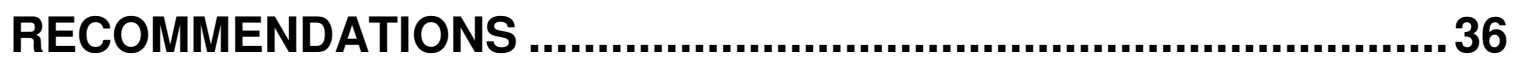

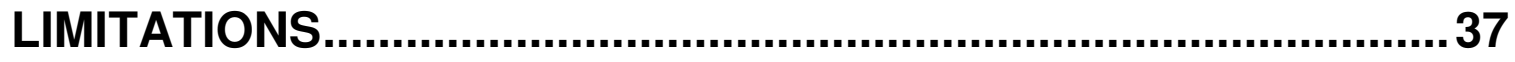

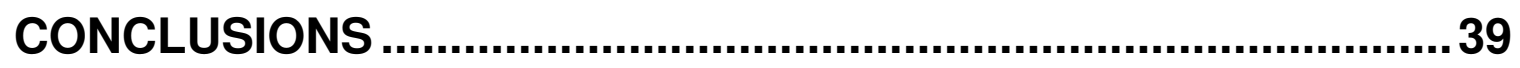

Appendix A............................................................................ 40

REFERENCES ......................................................................... 42 


\section{List of Figures}

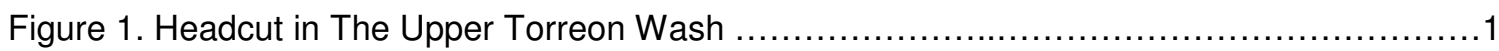

Figure 2. Study area, courtesy of the Rio Puerco Alliance. ......................................................... 2

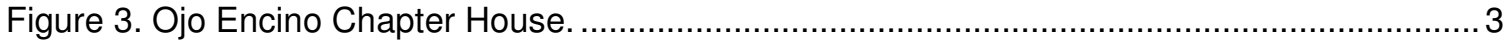

Figure 4. Climate parameters as modified by the WEPP program..........................................11

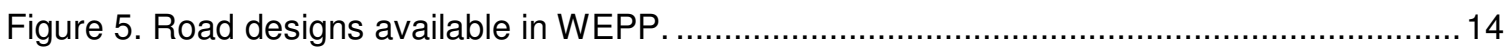

Figure 6. Outsloped rutted (left) and crowned with two ditches (right). .................................... 15

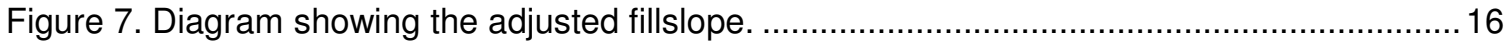

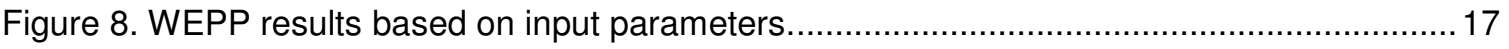

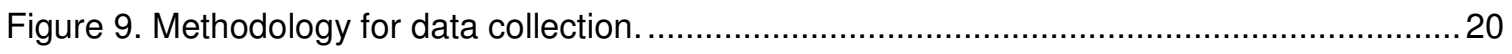

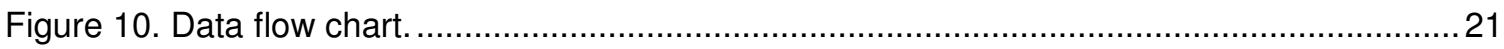

Figure 11. This road, crossing Torreon Wash, is also a vital bus route.......................................22

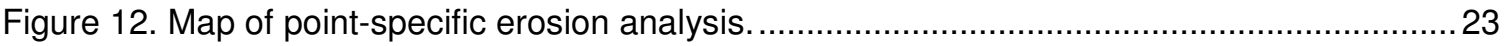

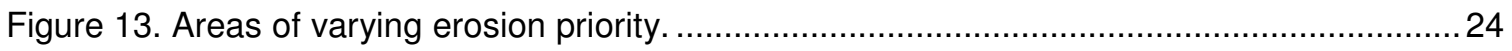

Figure 14. Stream Contributions Before and After Remediation. ............................................ 27

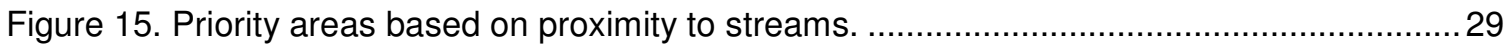

Figure 16. Twelve remediated roads in the study area.......................................................... 30

Figure 17. Example of rolling dip and water bar remediation efforts. ....................................... 31

Figure 18. Reduced road erosion for remediated roads.......................................................... 34

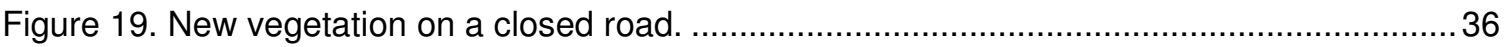




\section{List of Tables}

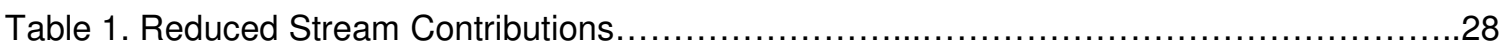

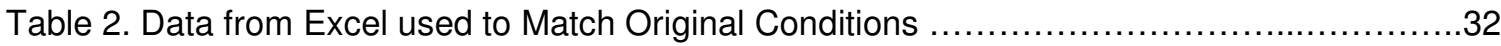

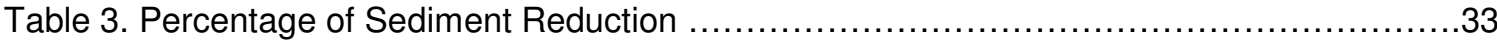

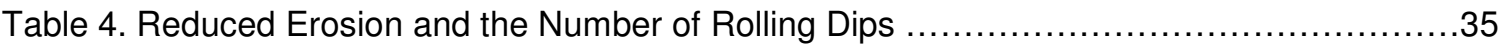

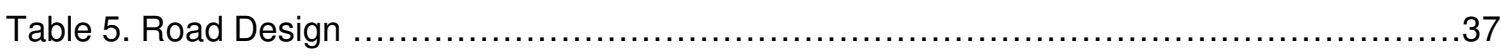




\section{INTRODUCTION}

\section{Rio Puerco Basin}

The upper Torreon Wash in northwestern New Mexico is a tributary to the Rio Puerco. The Rio Puerco has gained worldwide attention due to extremely high erosion rates. "Compared to World Rivers, the Rio Puerco basin in central New Mexico transports one of the world's highest average annual sediment concentrations" (Gellis, 2006). The Rio Puerco drains to the Rio Grande river system at Bernardo south of Albuquerque. While the Rio Puerco contributes only $4 \%$ of the annual water flow, it is responsible for an average of $70 \%$ of the total sediment load transported to the Rio Grande (Gellis, 2006).

A majority of the Rio Puerco watershed is impacted by significant landscape changes and arroyo incision; the causes of both remain undetermined. It is believed that the incision began in the 1880 s and has continued to the present (Aby et al., 2004). Today, the area has large head cuts and gullies and little or no riparian vegetation (Figure 1). The unusually

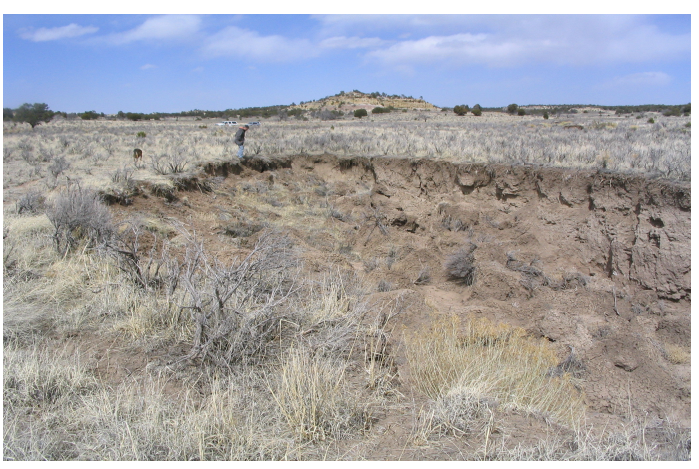

Figure 1. Headcut in the Upper Torreon Wash. high sediment rates prompted the federal government to form the Rio Puerco Management Committee, established by U.S. Public Law 104-333 (RPMC, 2008). 


\section{Study Area}

The study area (Figure 2), known as the upper Torreon Wash, is approximately 200 square miles, with land ownership by private, state, tribal, and federal entities. According to the Rio Puerco Alliance (2007), the area includes 11 land-status designations, which makes the area highly diverse.

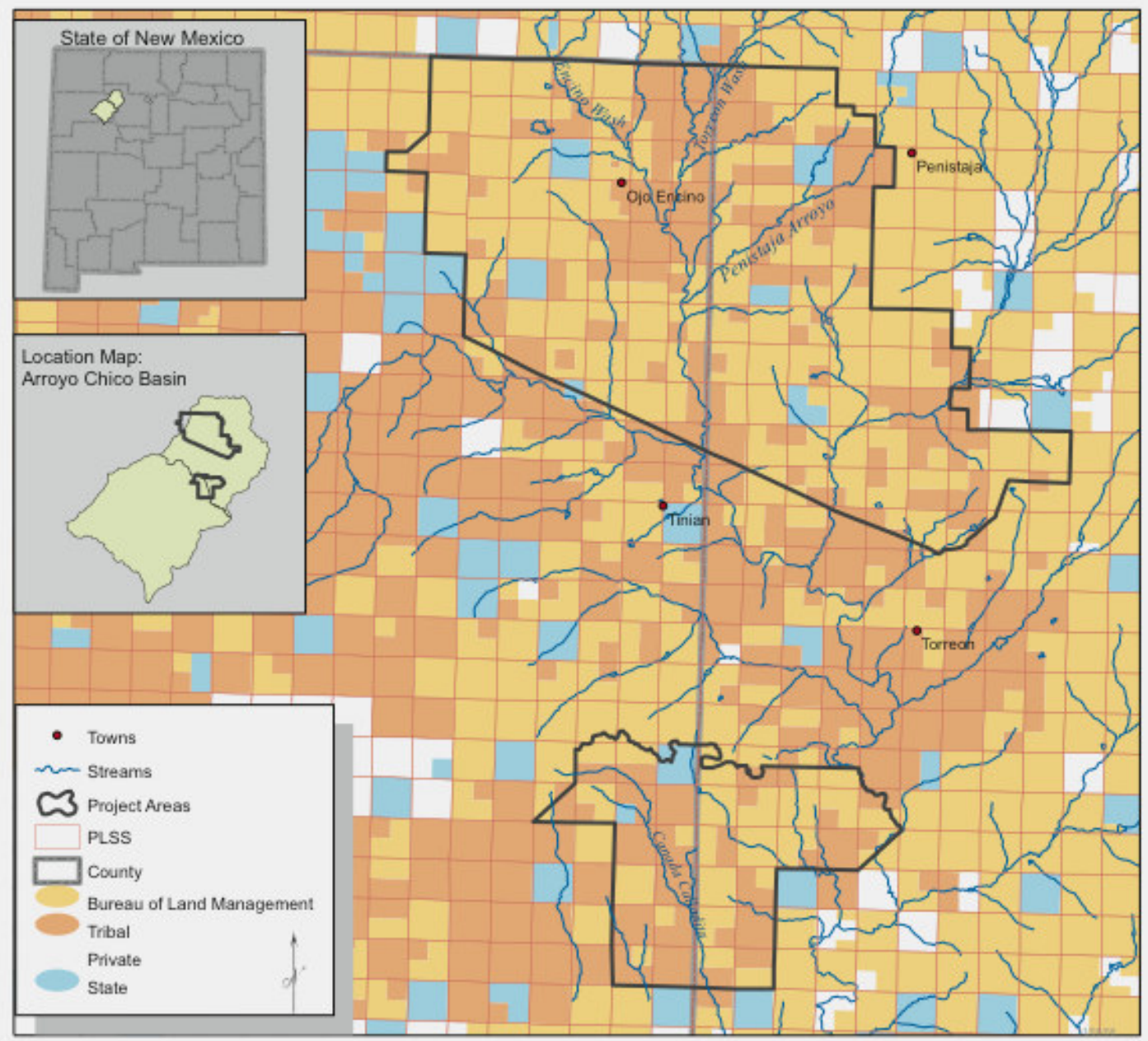

Figure 2. Study area, courtesy of the Rio Puerco Alliance. 
The project described in this report was commissioned by the Rio Puerco Alliance in conjunction with the Rio Puerco Management Committee and the Bureau of Land Management. The study area surrounds the community of Ojo Encino, New Mexico (Figure 3).

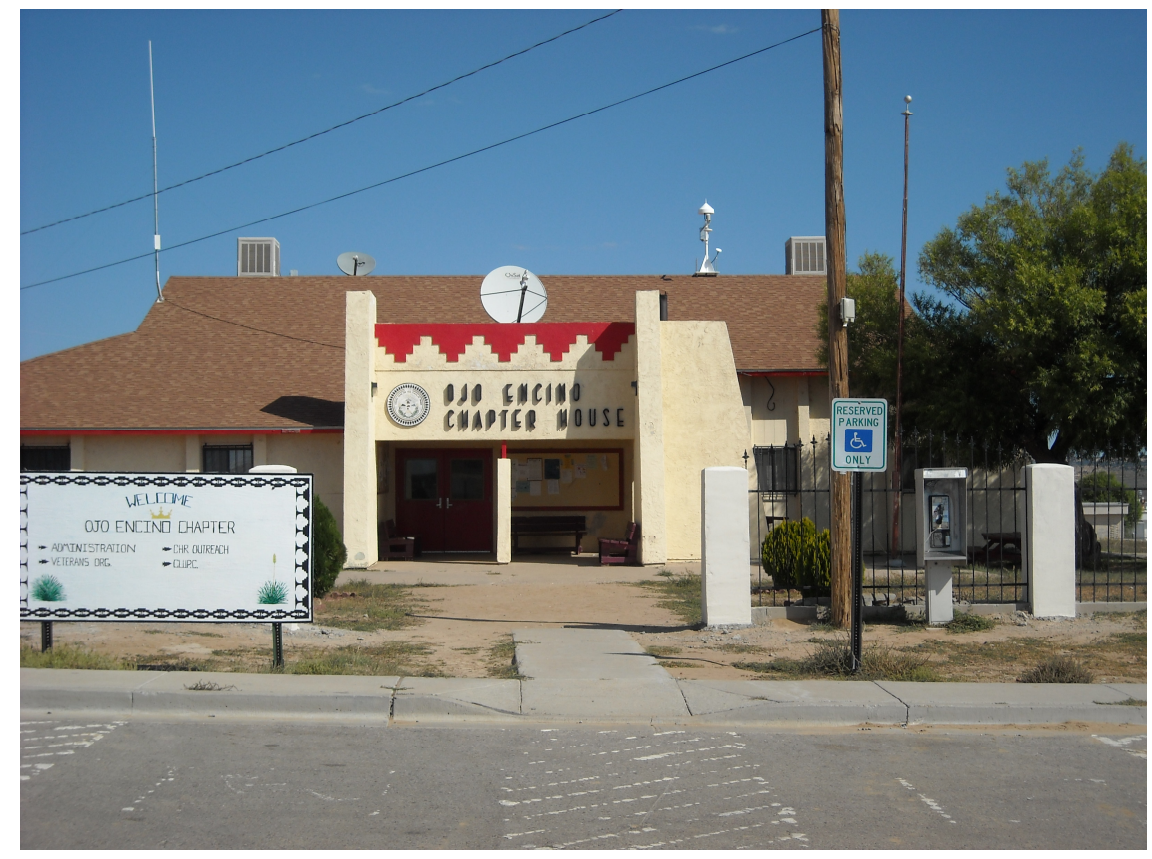

Figure 3. Ojo Encino Chapter House.

Ojo Encino (Spanish for Oak Springs) was established in 1951. Ojo Encino is found within the Navajo Nation, and the roads provide access to lands surrounding the community. Most of the roads are unpaved. The main roads are regularly bladed and maintained by the Bureau of Indian Affairs. Other road segments are created and maintained by the community. 


\section{Project Objectives}

Due to erosion, roads are thought to be large contributors of sediment because they act as channels or conduits that accelerate sediment transport and delivery. Road networks within the upper Torreon Wash are especially problematic because they are mainly unpaved surfaces, where erosion is a constant issue. A sediment budget analysis can be estimated using the Water Erosion Prediction Project. A quantitative analysis of potential erosion will allow stakeholders to better understand mitigation efforts and to make informed decisions regarding erosion control.

The purpose of this investigation was to evaluate multiple roads for attributes that are specific to the Water Erosion Prediction Project (WEPP) software program. The data were compiled using geographic information systems (GIS) to provide a foundation that captures attribute information, with a spatial component that can be illustrated using GIS mapping technology. Input parameters are processed through the WEPP model, which evaluates the data and determines mean annual averages of road erosion and the sediment from the road that is routed over the landscape.

The work addressed three basic objectives:

- To establish a starting point for future mitigation efforts, initial data were collected by mapping and identifying areas with potentially high erosion rates. 
- To perform a detailed analysis that measured the impact of past road remediation that attempted to decrease sediment transport and delivery.

- To identify sediment delivery to streams in order to determine if remediation efforts improved stream quality.

\section{THE WEPP MODEL}

\section{Background}

The WEPP soil erosion model was developed by a team of scientists from the U.S. Department of Agriculture (USDA) Agricultural Research Service, Natural Resources Conservation Service (NRCS); the Forest Service; the Bureau of Land Management; and the U.S. Geological Survey (USGS). This interagency group of scientists has been working on the model since 1985; the model is intended to replace the universal soil loss equation (USLE) (Elliot, 2004). The original purpose of WEPP was to model small watersheds, where USLE cannot be used.

The original WEPP model was created as a desktop application designed to model watersheds. However, the program was cumbersome, and the use of the program was becoming extinct (Elliot, 2004). The desktop version was altered and designed as a web-based version to specifically look at road erosion and disturbed conditions. Two program interfaces were used, specifically designed to predict erosion from roads, those of WEPP: Road and WEPP: Road Batch. The WEPP model simulation has been proven to closely match observed 
sediment loss and to accurately predict future erosion potential (Flanagan et al., 2000). When tested against USLE technology, the results were similar, making WEPP technology a useful alternative (Laflen et al., 2004).

\section{Weather Generator}

The Forest Service WEPP interface includes the Rock: Clime weather generator. This allows users to create custom climates using the CLIGEN program to compute equations and algorithms for various components of the weather generator (USDA, 2008). The principal calculations discussed herein include the number of wet days, the amount of precipitation, the storm duration, and the time to peak. The program also calculates the air temperature, solar radiation, dew point temperature, and the wind speed and direction.

To determine the number and distribution of precipitation events, the program uses a two-state Markov chain. The two conditional probabilities involve a wet day following a dry day and a dry day following a wet day, as well as any combination of these. In order to transition from one season to the next, twelve monthly values are calculated. To determine a wet or dry day, the program uses random sampling of monthly distributions (Nicks et al., 1995).

The program determines if there is precipitation on any given day, and the amount is decided using skewed normal distribution (Nicks et al., 1995).

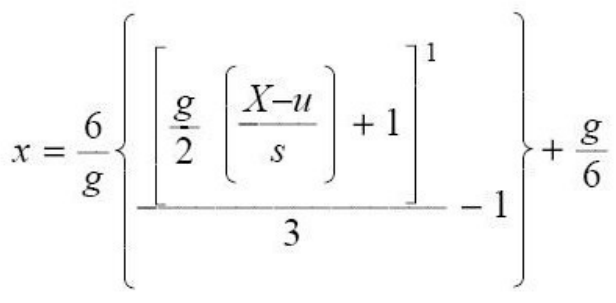

Where: $x$ is the standard normal variate $X$ is the raw variate $u$ is the mean coefficient of the raw variate $s$ is the standard deviation $g$ is the skew coefficient of the raw variate 
The skew coefficient and mean standard deviation are calculated for each month. A random normal deviate is drawn and the raw variate or daily amount is calculated (Nicks et al., 1995). The program decides if the precipitation is rain or snow, based on the maximum daily temperature. If the temperature is below $0^{\circ} \mathrm{C}$, then the precipitation is assumed to be snow; otherwise, it is considered to be rain (Nicks et al., 1995).

Storm duration is also calculated, and it is assumed that the duration of storm events is exponentially related to mean monthly duration based on the following equation:

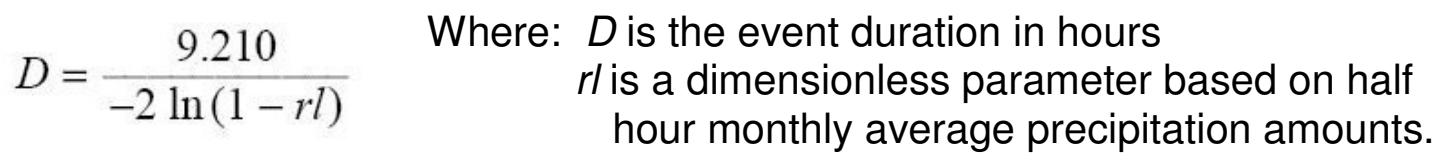

Peak storm intensity is estimated by calculating the annual accumulated distribution of time to peaks and is taken from data at the National Weather Service 15-min recording stations (Nicks et al., 1995) Precipitation amounts are recorded to the nearest 0.10 inch. The time to peak is then calculated using the first precipitation interval to the mid-point of the 15-min interval that contains the peak intensity. A distribution is constructed of time to peak for all storms throughout the year. Specific time to peak data can be derived by sampling the accumulated distribution with a random deviate between 0.0 and 1.0 (Nicks et al., 1995).

CLIGEN is supplemented with the Parameter Elevation Regression on Independent Slopes Model (PRISM), which was developed by the University of 
Oregon. PRISM is a sophisticated climate map that uses regional regression relationships to predict monthly precipitation values (Elliot, 2004).

\section{Winter Hydrology}

The WEPP model can simulate a variety of factors on an hourly basis, including three of the program's subcomponents: snow accumulation, snow melt, and the frost-thaw of the soil. Snow accumulation predicts snow depth and density. Precipitation is considered snow when the maximum daily temperature is below $0^{\circ} \mathrm{C}$. The snow-melt component is figured hourly and accounts for the infiltration capacity of the soil. Snow cannot melt if the temperature is below $-2.8^{\circ} \mathrm{C}$. The frost-thaw subcomponent estimates frost and thaw over the winter period and accounts for infiltration and runoff during winter months (Savabi et al., 1995).

\section{Surface Hydrology}

The WEPP model contains a hydrology component used to calculate the infiltration rate and the rainfall-excess rate. Infiltration is calculated using the Green-Ampt Mein-Larson model, which had been modified to calculate for unsteady intermittent rainfall. Rainfall excess occurs when the rainfall rate exceeds the infiltration rate. The infiltration process has two stages: (1) ground surface has no ponding, and (2) ground surface has ponded with water. Infiltration rates can change between the two stages, but runoff occurs only when the ground surface has ponded with water. Without ponding, all the rainfall will infiltrate into the soil. The amount of rainfall considered runoff occurs once the soil has reached the infiltration capacity. The rainfall excess hydrograph is 
transformed into a time-intensity distribution of runoff by using the kinematic wave model (Stone et al., 1995).

\section{Water Balance}

The WEPP model maintains a water balance on a daily basis. The soil water content in the root zone is determined by the cumulative precipitation, precipitation intercepted by vegetation, water content, surface runoff, evapotranspiration, and the percolation loss below the root zone. The amount of soil water in the root zone impacts runoff events, the rate of plant growth, and residue decomposition (Savabi and Williams, 1995).

\section{Soil Component}

The soil properties influence the basic water erosion process, which includes bulk density, wetting front suction, hydraulic conductivity, interill erodibility, rill erodibility, and critical sheer stress. The bulk density refers to the pore volume of the soil, used to determine the wetting front suction. The most important parameter is the effective hydraulic conductivity; this controls the prediction of infiltration and runoff. The interill erodobility is a measure of the soil resistance to detachment by a raindrop. The rill erodobility is a measure of the resistance to detachment by flow, which is dependent on the critical sheer stress of the flow (Alberts et al., 1995). The values used to calculate these parameters are dependent on the soil type and are listed in Appendix A.

\section{Plant Growth}

Vegetative cover is not a direct input parameter for WEPP. Instead, the model runs each simulation based on climate data, soil water content of multiple 
layers, plant growth, residue decomposition, and senescence, calculated from daily values. The result is vegetative cover based on the biomass energy conversion ratio, temperatures, growth and temperature-based decomposition rates, and availability of soil water (Elliot, 2004).

\section{Erosion Component}

Erosion calculations are essential elements in the WEPP program. The program determines how erosion is occurring as well as the ability of water to transport sediment loads. Interrill erosion is described as particle detachment by raindrop impact. The interill delivery rate is described as transport by shallow sheet flow and sediment delivery to rill channels, where it can be carried off the hillside by flow or deposited in the rill. Rill erosion describes the ability of concentrated flow to detach and transport sediment loads; rill erosion is positive for detachment and negative for deposition. Calculations used to predict erosion include flow sheer stress, depth of flow, and the sediment transport capacity (Foster et al., 1995).

\section{Climate}

\section{WEPP INPUT PARAMETERS}

Data for this project were extracted from the Torreon Navajo Mission, approximately 20 miles from the study area; the Mission contains 32 years of record. PRISM data were used to create a custom climate by entering the latitude $\left(107.34^{\circ} \mathrm{W}\right)$ and longitude $\left(35.95^{\circ} \mathrm{N}\right)$ of the study area, calculated at the chapter house in Ojo Encino, N.M. The elevation was adjusted to 6,760 feet above sea level, and the adiabatic lapse rate was applied to adjust temperatures 
for the revised elevation; this rate adjusts the temperature by 6 degrees $/ \mathrm{km}$ for maximum temperatures and 5 degrees $/ \mathrm{km}$ for minimum temperatures (Elliot, 2004). The climate file was stored in WEPP and listed as Ojo Encino, N.M. The study area receives an average annual precipitation of $10.27 \mathrm{in} / \mathrm{yr}$ when averaged over a 200-year timeframe (Figure 4).
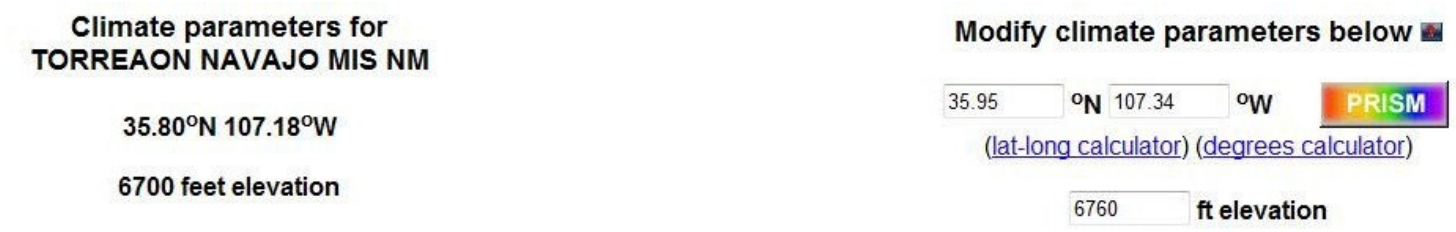

\begin{tabular}{|c|c|c|c|c|c|c|c|c|}
\hline $\begin{array}{c}\text { Mean } \\
\text { Maximum } \\
\text { Temperature } \\
\left({ }^{\circ} \mathrm{F}\right)\end{array}$ & $\begin{array}{c}\text { Mean } \\
\text { Minimum } \\
\text { Temperature } \\
\left({ }^{\circ} \mathrm{F}\right)\end{array}$ & $\begin{array}{l}\text { Mean } \\
\text { Precipitation } \\
\text { (in) }\end{array}$ & $\begin{array}{l}\text { Number } \\
\text { of wet days }\end{array}$ & Month & $\begin{array}{c}\text { Mean } \\
\text { Maximum } \\
\text { Temperature } \\
\left({ }^{\circ} \mathrm{F}\right)\end{array}$ & $\begin{array}{c}\text { Mean } \\
\text { Minimum } \\
\text { Temperature } \\
\left({ }^{\circ} \mathrm{F}\right)\end{array}$ & $\begin{array}{c}\text { Mean } \\
\begin{array}{c}\text { Precipitation } \\
\text { (in) }\end{array}\end{array}$ & $\begin{array}{l}\text { Number } \\
\text { of wet days }\end{array}$ \\
\hline 40.41 & 14.34 & 0.51 & 4.25 & January & 40.21 & 14.18 & 0.51 & 4.25 \\
\hline 46.50 & 20.17 & 0.44 & 4.00 & February & 46.3 & 20.01 & 0.44 & 4.00 \\
\hline 55.18 & 25.13 & 0.54 & 4.16 & March & 54.98 & 24.97 & 0.54 & 4.16 \\
\hline 65.53 & 31.08 & 0.51 & 3.00 & April & 65.33 & 30.92 & 0.51 & 3.00 \\
\hline 74.90 & 39.92 & 0.75 & 4.19 & May & 74.7 & 39.76 & 0.75 & 4.19 \\
\hline 85.37 & 48.86 & 0.54 & 3.00 & June & 85.17 & 48.7 & 0.54 & 3.00 \\
\hline 88.66 & 56.06 & 1.48 & 8.20 & July & 88.46 & 55.9 & 1.48 & 8.20 \\
\hline 85.40 & 54.31 & 1.76 & 8.36 & August & 85.2 & 54.15 & 1.76 & 8.36 \\
\hline 78.12 & 47.02 & 1.23 & 5.60 & September & 77.92 & 46.86 & 1.23 & 5.60 \\
\hline 67.61 & 35.46 & 1.02 & 4.25 & October & 67.41 & 35.3 & 1.02 & 4.25 \\
\hline 52.48 & 24.62 & 0.68 & 3.80 & November & 52.28 & 24.46 & 0.68 & 3.80 \\
\hline 42.43 & 16.46 & 0.56 & 3.73 & December & 42.23 & 16.3 & 0.56 & 3.73 \\
\hline & & 10.02 & 56.54 & Annual & & & 10.02 & 56.54 \\
\hline \multicolumn{5}{|c|}{ Change entire column (enter 0 to reset) $>>$} & $+1-0$ & $+1-0$ & $+1-0$ & $+1-\overline{0}$ \\
\hline
\end{tabular}

ه Adiust temperature for elevation by lapse rate

Figure 4. Climate parameters as modified by the WEPP program.

\section{Number of Years Simulated}

The WEPP model uses a daily time step, with results given in mean annual averages. The WEPP program will run for a 30-yr period, but in climates with precipitation 19 inches a year of precipitation be run for a minimum of 50 
years (Elliot et al., 1999). In drier climates there can be a variation in dry years and wet years. To ensure that an adequate number of wet years are represented the program should be run for a longer time frame to ensure a stable average erosion value. For this analysis the program was run for a period of 200 years.

\section{Soil Characteristics}

Soil textures are restricted to four basic types:

- Clay loam.

- Silt loam.

- Sandy loam.

- Loam.

"The erosion potential of a given soil depends more on the vegetation cover than the soil texture" (Elliot et al., 1999).

Soil parameters include albedo of surface soil, interrill erodibility, rill erodibility, critical sheer, effective hydraulic conductivity, percentage of sand and clay, organic matter, and the cation-exchange capacity.

To establish the best soil type for the study area, the Web Soil Survey was used, developed by the USDA and the NRCS from information derived from the National Cooperative Soil Survey partnership (USDA-NRCS, 2008). The Web Soil Survey contains detailed information related to the study area.

The major soil types are Tsosie-Councelor-Blancot loams near Torreon Wash, Doakum-Betonnie complex around the village of Ojo Encino, and the Councelor-Eslendo-Calladito complex found in the southern half of the study area. These three soil types contain roughly the same soil texture and are 
present in nearly $80 \%$ of the study area. Soil parameters allowed by WEPP were compared with site-specific information to identify the soil type that would best be suited to the conditions in the area. Available data compared against the WEPP parameters included the effective hydraulic conductivity, percentage of sand and clay, percentage of organic matter, and the cation-exchange capacity. The comparison suggested loam would offer the best fit for the study area (see Appendix A).

\section{Road Attributes}

Information collected in the field included road length, width, and gradient. Length was gathered using a distance-measuring wheel that is routed over the road to determine length and width. Gradient was determined using a hand-held clinometer; all measurements were performed with the assistance of a field partner.

In WEPP equations, the road design plays an important role in determining the sediment yields and runoff paths that result from critical sheer, rill, and interrill calculations. The road design was chosen from four possible conditions: insloped bare ditch, insloped vegetated, outsloped rutted, and outsloped unrutted (Figure 5). 


\section{WEPP:Road Road Designs}
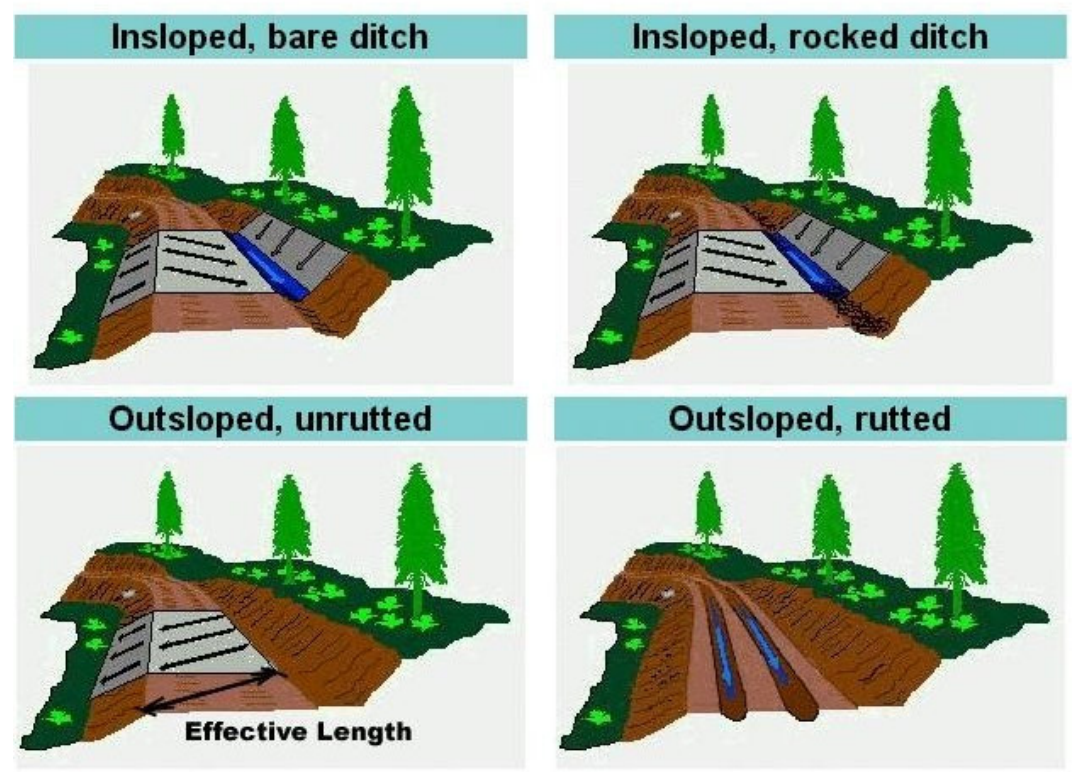

Figure 5. Road designs available in WEPP.

However, the road design options within WEPP are specific to forested areas. The options are based on a "cut and fill" design with a cut slope and a fillslope. In most cases, this was not representative of the study area. The topography consisted of rolling hills with low gradients, and no observed roads contained "cut and fill" designs.

The roads in the study area were predominantly outsloped rutted or crowned with two ditches, the latter of which is not a WEPP option (Figure 6). The outsloped rutted applies to roads where runoff follows the ruts for the length of the road. Crowned with two ditches applies to roads that are frequently bladed, resulting in water diversion to an inside ditch. The WEPP insloped bare option (not directly applicable to the study area) requires measurement of the road width, including the ditch width. Because the roads were frequently crowned with 
two ditches, this required the WEPP-user to modify the insloped bare option by recording half the road length, including the ditch, and doubling the predicted sediment yields (William J. Elliot, pers. comm.).

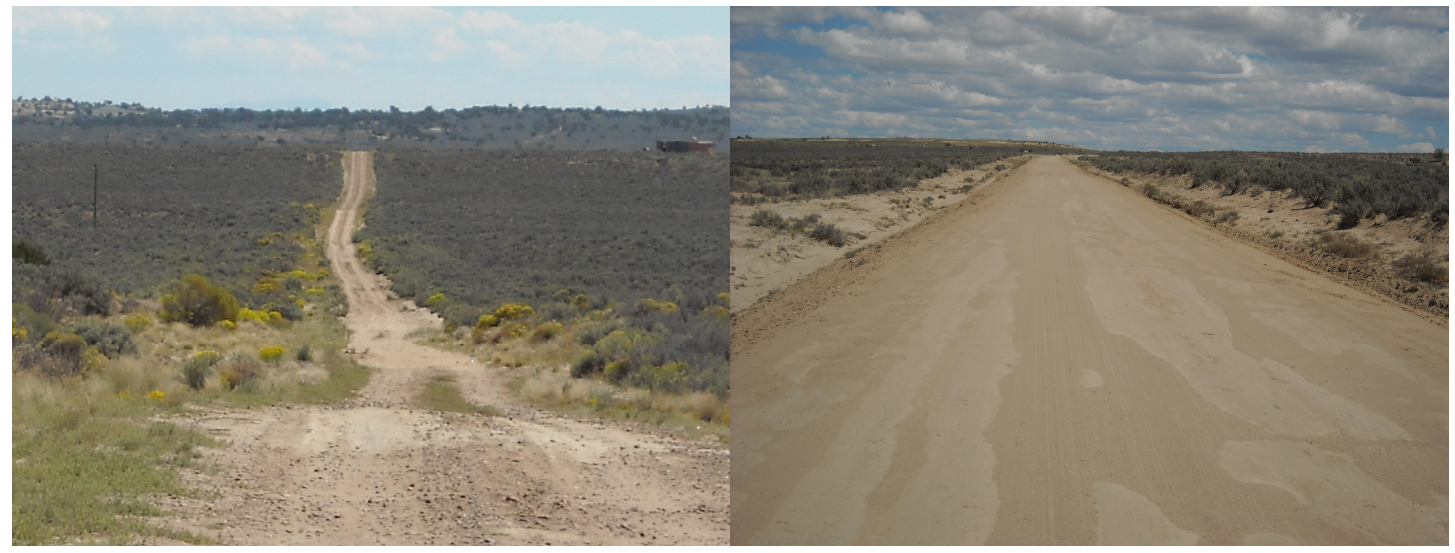

Figure 6. Outsloped rutted (left) and crowned with two ditches (right).

The road surface refers to the material—native, gravel, or paved—used to create the road. All roads surveyed were constructed of native material. In addition, the WEPP program assumes all road surfaces are void of vegetation (Elliot et al., 1999).

\section{Fillslope and Buffer}

The WEPP program acknowledges three overland flow elements: a road, a fillslope, and a forest buffer (Elliot et al.,1999). The fillslope refers to the shoulder of a road. The buffer refers to the adjacent landscape. WEPP requires a buffer length and gradient, but the program assumptions were developed for forested areas; therefore, these parameters were modified: The program assumes $100 \%$ forest litter or ground cover in the buffer areas and $50 \%$ ground cover in the fillslope. The second assumption better represents the conditions in 
the study area; this was used to create an adjusted fillslope (Figure 7). According to Bill Elliott, Project Leader for WEPP, the lack of vegetation in the area can be better quantified by substituting the fillslope parameter (50\%) for the forested buffer, and then running minimum values for the buffer length and gradient (William J. Elliot, pers. comm. e-mail 7/25/08 Subject: Roads in GIS).

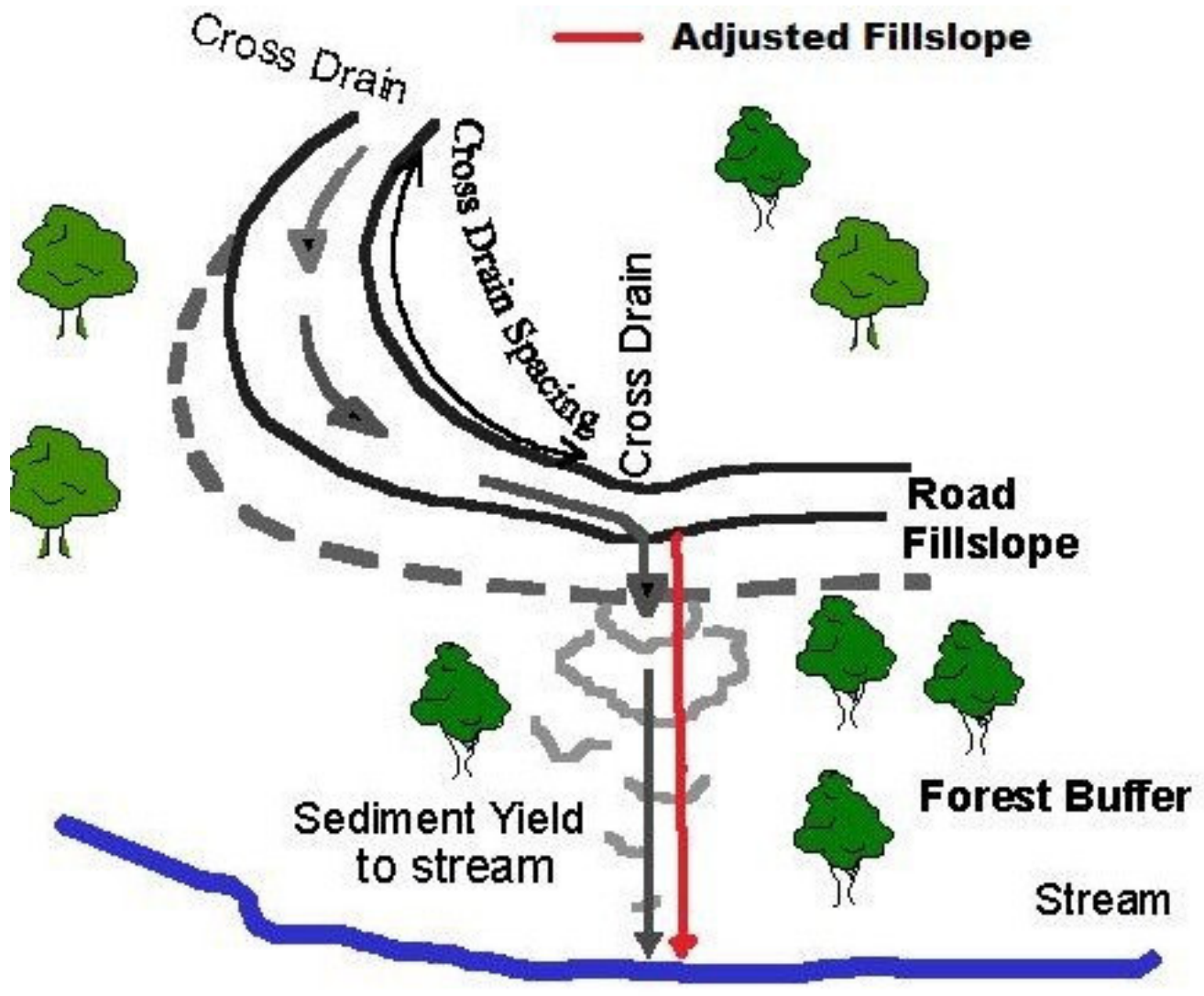

Figure 7. Diagram showing the adjusted fillslope.

The fillslope gradient was measured in the field using a clinometer, while the length was determined using the ArcView measuring tool. The width across a fillslope area was assumed to be the width of the road (Elliot, 2004). 


\section{Percent of Rock Fragments}

The percentage of rock fragments has an important effect on the hydraulic conductivity. Overall, unpaved roads have low hydraulic conductivity, with values generally less than $0.1 \mathrm{~mm} / \mathrm{hr}$ (Brooks et al., 2006). WEPP reduces the hydraulic conductivity of the soil in direct proportion to the rock content. For example, an input of $20 \%$ rock will reduce the hydraulic conductivity by $20 \%$ (WEPP, 2008). Based on observed data, there were no rock fragments on any of the roads surveyed for this study, so the percentage was entered as zero.

\section{WEPP Analysis}

The WEPP results are based on the road sections shown in Figure 8; the input parameters already described are displayed, as well as the WEPP program

\section{WEPP:Road Results}

\begin{tabular}{|c|c|c|c|}
\hline \multicolumn{4}{|c|}{ INPUTS } \\
\hline Climate & \multicolumn{3}{|c|}{$\begin{array}{l}\text { Ojo Encino, N.M. + } \\
\text { Modified by Rod:Clime on November } 11,2008 \text { from TORREAON NAVANO MIS NM } 2990310 \\
\text { T MAX 40.21 46.30 } 54.9865 .3374 .7085 .1788 .4685 .2077 .9267 .4152 .2842 .23 \text { deg F } \\
\text { T MIN } 14.1820 .0124 .9730 .9239 .7848 .7055 .9054 .1546 .8635 .3024 .4616 .30 \mathrm{deg} \text { F } \\
\text { MEANP } 0.510 .440 .540 .510 .750 .541 .481 .781 .231 .020 .680 .58 \text { in } \\
\text { \# WET 4.25 4.00 } 4.163 .004 .193 .008 .208 .365 .604 .253 .803 .73\end{array}$} \\
\hline Soil texture & \multicolumn{3}{|c|}{$\begin{array}{l}\text { loam with } 0 \% \text { rock fragments } \\
\text { (road: } 0 \% \text {; fill: } 0 \% \text {; buffer: } 0 \% \text { rook) }\end{array}$} \\
\hline Road design & \multicolumn{3}{|l|}{ Outsloped, rutted } \\
\hline \multirow[t]{2}{*}{ Surface, traffic } & \multicolumn{3}{|l|}{ native surface, high traffic } \\
\hline & $\begin{array}{l}\text { Gradient } \\
(\%)\end{array}$ & $\begin{array}{l}\text { Length } \\
\text { (ft) }\end{array}$ & $\begin{array}{l}\text { Width } \\
\text { (ft) }\end{array}$ \\
\hline Road & 3 & 194 & 9 \\
\hline Fill & 5 & 162 & \\
\hline Buffer & 0.3 & 1 & \\
\hline
\end{tabular}

200 - YEAR MEAN ANNUAL AVERAGES

10.27 in precipitation from

0.07 in runoff from rainfall from

0.01 in runoff from snowmelt or winter rainstorm from

$90.72 \mathrm{lb}$ road prism erosion

$30.55 \mathrm{lb}$ sediment leaving buffer
11338 storms

1952 events

361 events

Figure 8. WEPP results based on input parameters. 
results. Multiple road segments can be run through WEPP:Road Batch; this allowed all segments of each individual road to be evaluated during a single analysis. The program determines the number of pounds of road erosion and the sediment leaving the buffer or, in this case, the sediment leaving the fillslope.

\section{METHODOLOGY}

\section{Geographic Information System (GIS)}

The Geographic Information System (GIS), which allows data to be created, stored, and manipulated within a geographic environment, was used for mapping and illustrating roads within the study area. A base map was created within this system.

Data are referenced to the North American Datum of 1983 and are projected using the Universal Transverse Mercator (UTM) Zone13N, which is specific to New Mexico. To ensure consistency, all data were created or changed to match this condition.

Significant GIS data are available for the upper Torreon Wash. Initial data were derived using 2005 USGS digital ortho quarter quads (DOQQ), which contained digital aerial photographs. New shapefiles were created to identify various images on the DOQQ including fence lines, power lines, and paved roads. These features were verified during the field surveys in order to eliminate them from the actual erosion analysis. The assessment eliminated county roads that are beyond the jurisdiction of this project, as well as roads with oil and gas 
transmission pipelines beneath them that, due to their nature, cannot be disturbed.

\section{Global Positioning System (GPS)}

The field data were collected and stored in the data dictionary of a Trimbel GPS recorder. All data required for the WEPP analysis were recorded to expedite later use in the program. Because most roads in the study area have no formal name, a numbering system for road segments was incorporated into the data collection activities. The data dictionary was programmed to incorporate the following fields:

- ID Number

- Work

- Unique

- \# Road Segments

- High Point, Delivery Point, or Both

- Road Design

- Road Surface

- Traffic Level

- Road Length

- Road Gradient

- Road Width

- Fillslope Gradient

- Fillslope Length

- Buffer Gradient and Length (min)

- \% of Rock Fragment

- Comments

Because of the rolling nature of the terrain, each delivery point was framed by high points on each side. High points allowed water to move downhill in two opposite directions, and the delivery points were the lower road areas where water left the road system and was delivered to the terrain. 
Most delivery points were situated between two adjacent high points; high points were therefore recorded as a frame of reference (and for later accountability), but no analyses data were associated with them. In this study, a segment was defined as the area between the high point and the downslope delivery point. In some cases, this resulted in two delivery points, as shown in Figure 9.

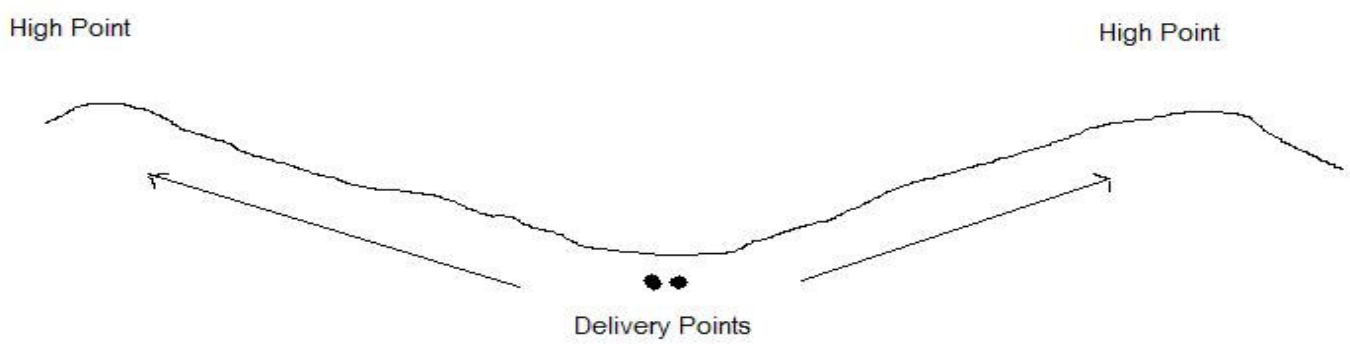

Figure 9. Methodology for data collection.

The Trimble GPS unit stores data that can be extracted by using the GPS pathfinder tool. The GPS pathfinder tool software then uses differential corrections for increased accuracy. The Trimble GPS unit was accurate to within $1 \mathrm{~m}, 84 \%$ of the time. The data were extracted and stored as a shapefile that can be added to the GIS with the corresponding attribute information.

\section{Evaluating the Road Network}

The road assessment was conducted with a field partner who assisted in the data collection. A total of 22 roads were surveyed. The roads chosen for this analysis were determined by a local official that was familiar with the road network. The analysis included 12 road segments where remediation had been 
completed. Remediation is on-going in the study area; therefore, other road segments were also analyzed as potential sites for remediation projects.

\section{Data Analysis}

Data gathered in the field were extracted from the GPS unit by using the GPS pathfinder tool. The information was added to the map as a shapefile, allowing the user to view the data points and their corresponding attribute information. The GIS attribute information was then exported and transferred to a Microsoft ${ }^{\circledR}$ Excel spreadsheet. The data were broken into individual road segments on which further analysis was conducted (Figure 10).

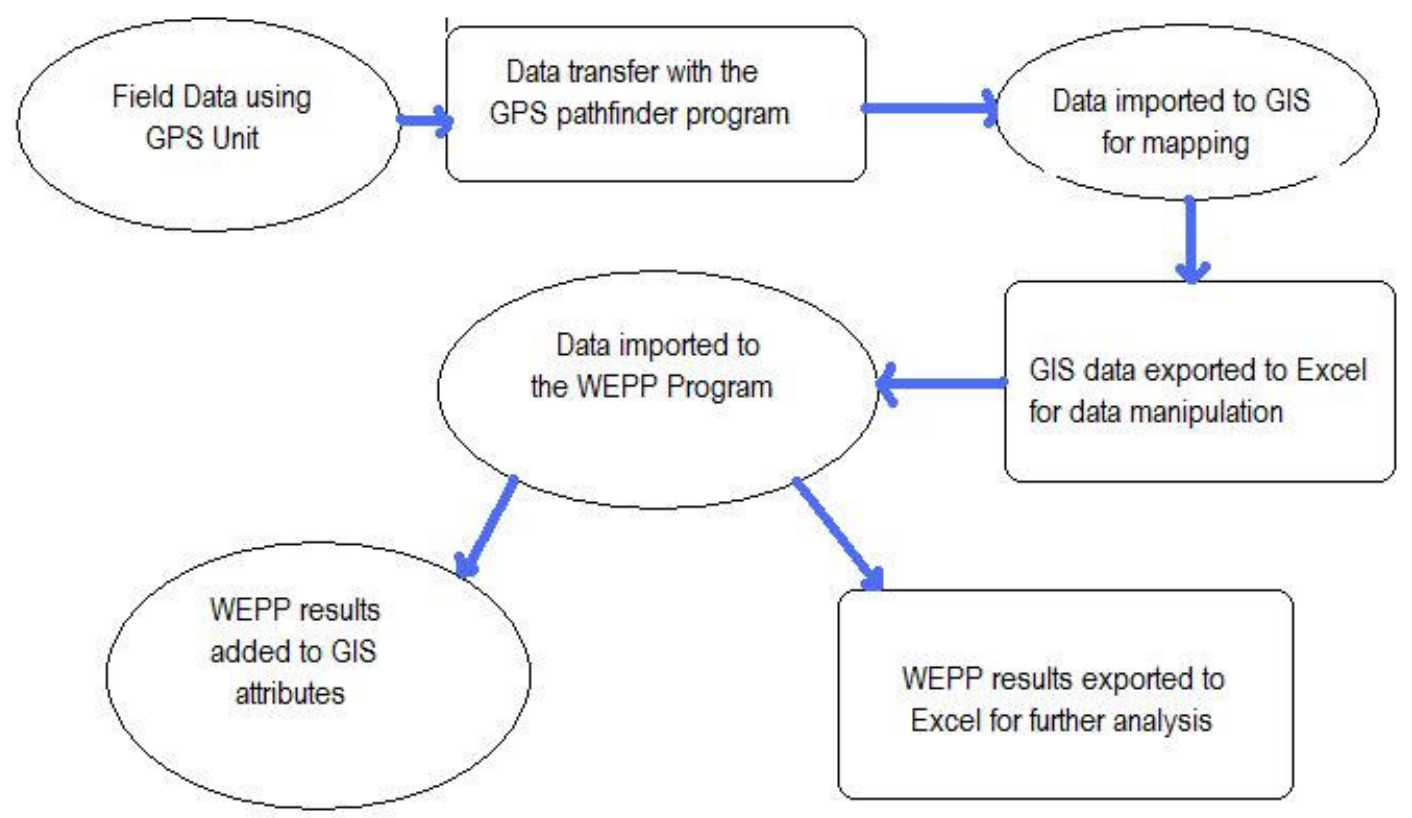

Figure 10. Data flow chart.

The WEPP program has a specific input format that was compiled in Excel and exported to the WEPP program. WEPP: Road Batch is capable of running 200 road segments at one time. To maintain the unique properties of each road, 
individual roads were run as one batch file. The WEPP results for each corresponding point were transferred back to Excel and were also incorporated into the GIS attribute table.

\section{RESULTS}

One objective of the analysis was to provide a foundation for future remediation work. The decision to use WEPP was based on Laflen's (2004) assertion that it was compatible with agency objectives concerning a wide range of conditions, and his findings suggested that the WEPP results could predict actual sediment loss in control studies.

Basic infrastructure problems from erosion can render a road impassible during storm events. This may create difficult conditions for local residents, who depend on roads for a variety of needs (Figure 11).

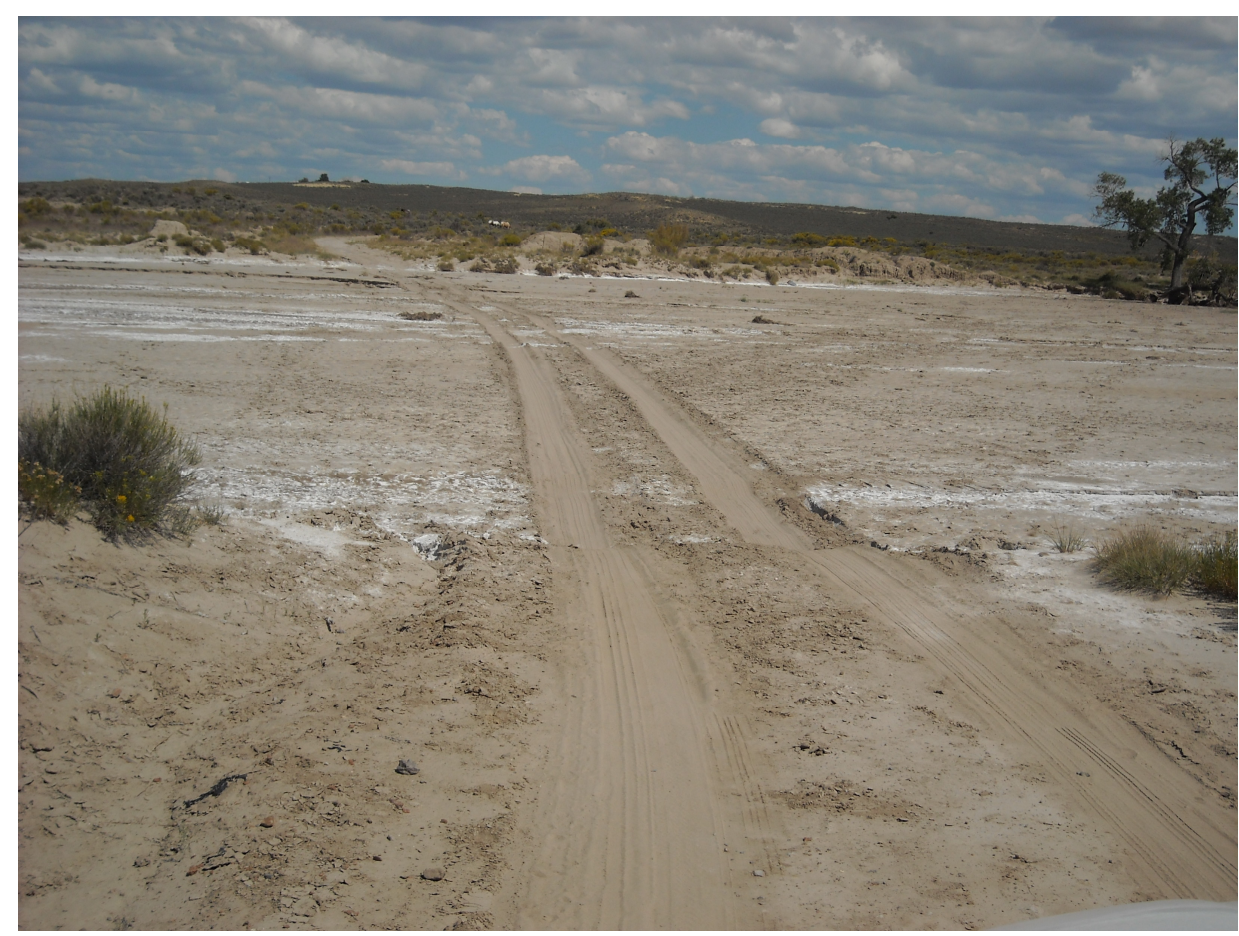

Figure 11. This road, crossing Torreon Wash, is also a vital bus route. 


\section{Erosion Hotspots}

Figure 12 shows the location where total road erosion was calculated. The data are a combination of one or more delivery points that drained to one specific location. The number of delivery points that contributed to each location was recorded, in the field, as a separate entry into the data dictionary. A sediment budget analysis was created for each drainage point in the system. The information was stored as a separate shapefile for use in GIS, which allows data to be changed or manipulated to meet future needs. This will allow stakeholders to evaluate high erosion areas and make decisions based on individual drainage points.

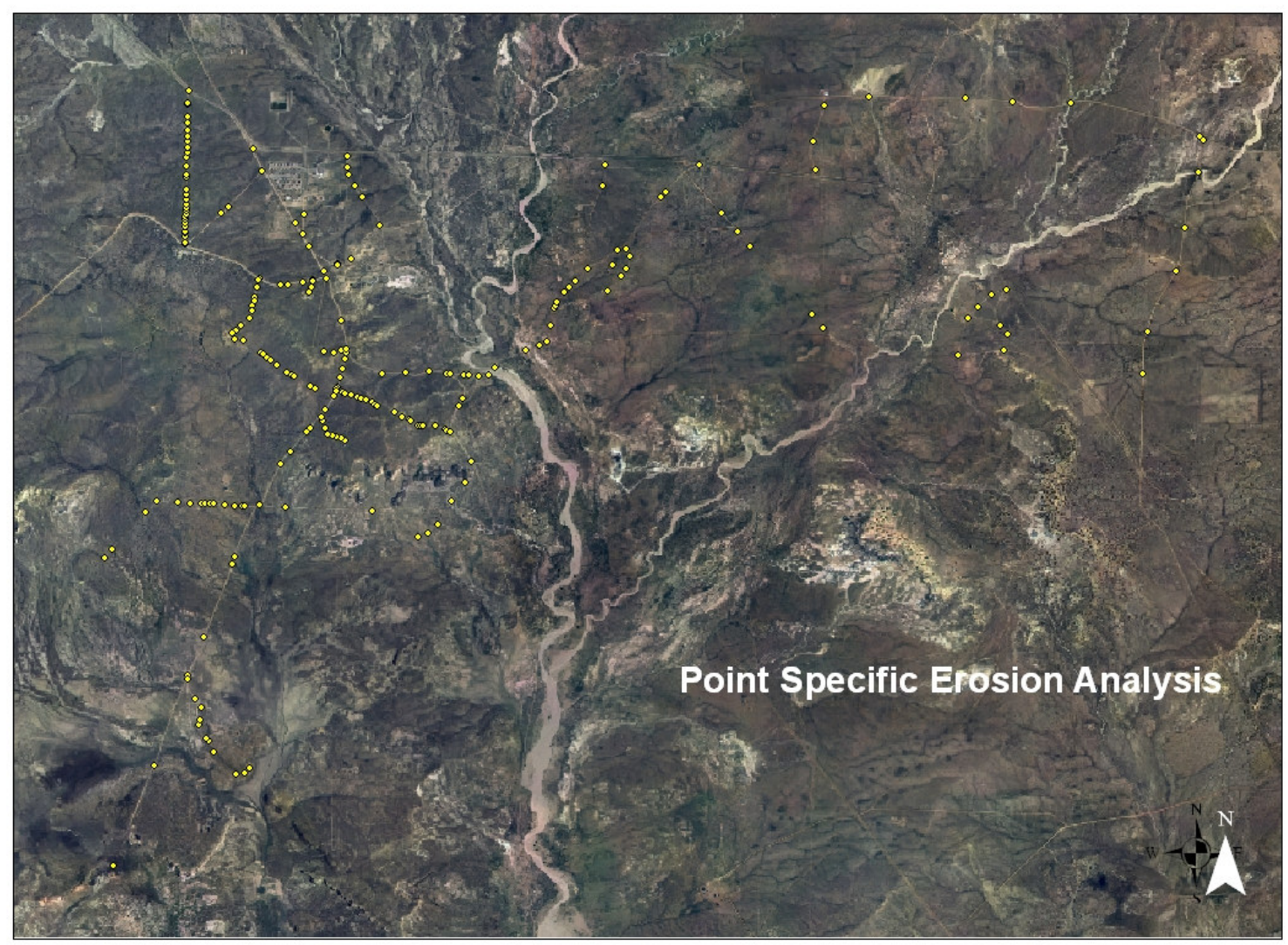

Figure 12. Map of point-specific erosion analysis. 


\section{Erosion per Mile}

The data for this study were normalized by dividing the sediment from the road by the length of the road. High priority areas were considered to be roads contributing more than $10,000 \mathrm{lb}$ of road sediment. The medium priority areas contained roads producing between 1,000 to $10,000 \mathrm{lb}$, and low priority roads produce less than $1,000 \mathrm{lb}$ (Figure 13). This method of analyzing road segments based on the amount of erosion per mile of road may be a useful foundation for future remediation.

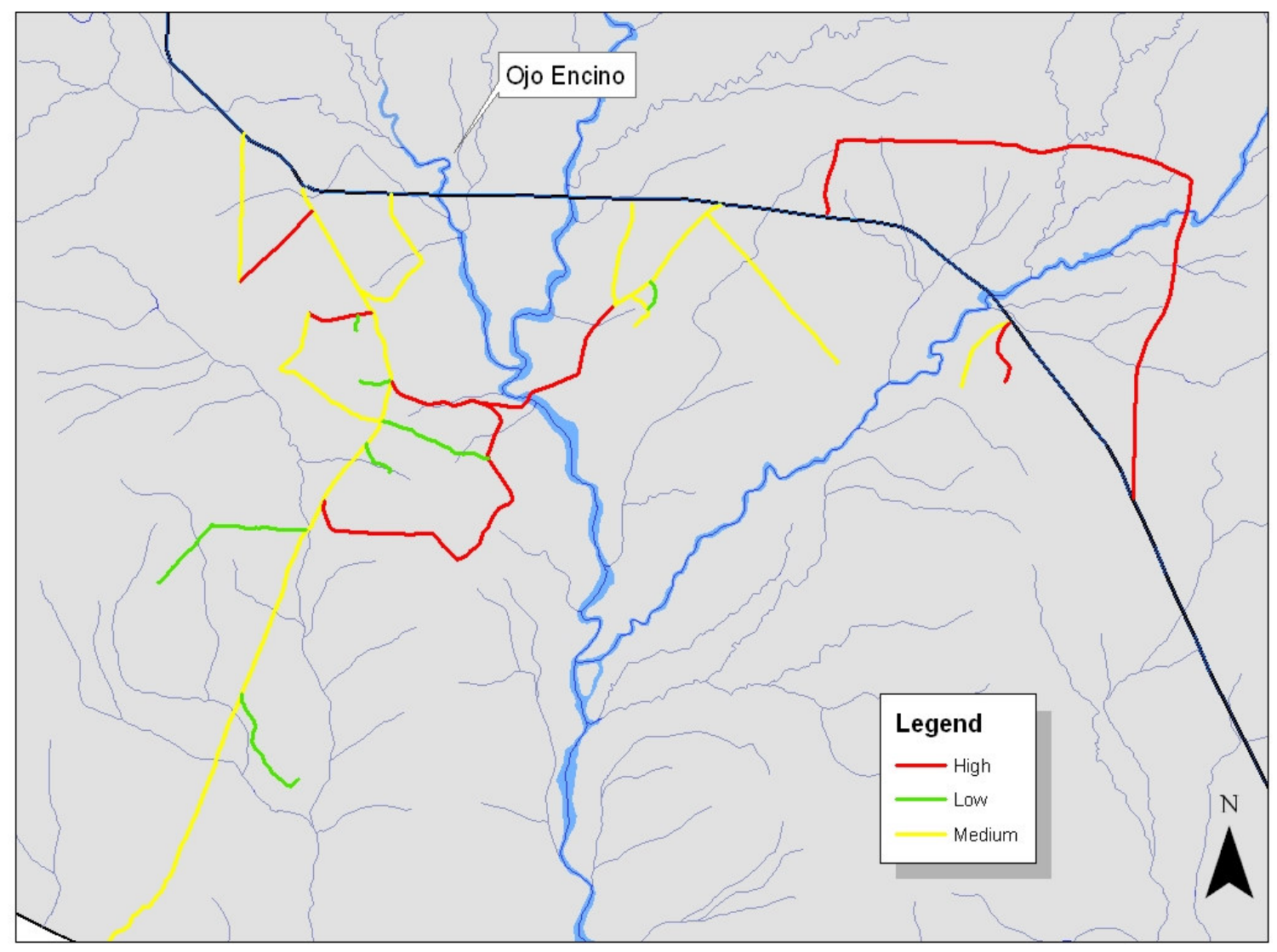

Figure 13. Areas of varying erosion priority. 


\section{Sediment Deposits to the Stream System}

The main issue surrounding the Torreon Wash is the high sediment loads that contribute to poor stream quality. The effects can be far reaching, with the sediment loads being routed through the network affecting the quality of downstream users. The analysis attempted to quantify the amount of erosion entering a stream from surveyed roads in the study area. Sediment can be delivered to a stream system two ways: (1) A road can intersect an ephemeral stream where it will deliver sediment from the surrounding road, or (2) it can be routed over the landscape where it is linked to a stream.

The National Hydrography Dataset (NHD), created by USGS, was used to identify stream networks and their proximity to roads. The NHD database identifies the stream segments or reaches, longer than 1 mile, that make up the national surface water drainage system. The high-resolution NHD data was developed at a scale of 1:24,000, a scale which adds a greater level of detail than previously existed (USGS, 1998). The NHD lines were the standard used to determine the proximity of streams to a road, and the data were used to determine the distance between a road and an NHD line.

All delivery points were analyzed to determine if the road directly intersected an NHD line or if the sediment coming from a road could be routed over the landscape and linked to a stream. Depending on the scenario, all information was documented either in the comment section or as a specialized field. Delivery points that did not contribute to the stream were also noted, but not 
addressed, even though it is important to observe that sediment can still pose a threat to the landscape by stifling vegetative growth.

The analysis totaled 22 roads within the study area, including remediated roads and roads without intervention. The data were calculated using only delivery points where the sediment was capable of reaching an NHD line, either directly or indirectly. Total sediment delivery from surveyed roads amounted to 84,006 pounds. The data were based on sediment routed over the landscape. Although a stream may intersect an NHD line, there is still some distance that it must travel before sediment enters the stream; this distance is the same as the fillslope length, which is recorded at each delivery point and is accounted for by WEPP.

Of special interest is the effect from the remediation efforts, discussed in the next section. The objective of this portion of the analysis was to quantify the effects of rolling dips on sediment delivery to streams. The analysis was designed to separate data in order to account for the 12 roads on which remediation had been completed. The data was further divided by looking at only the delivery points that were capable of reaching an NHD line because the purpose was to evaluate only erosion capable of entering streams (Figure 14). Therefore, delivery points that drained to a field or pond were eliminated from this analysis. 


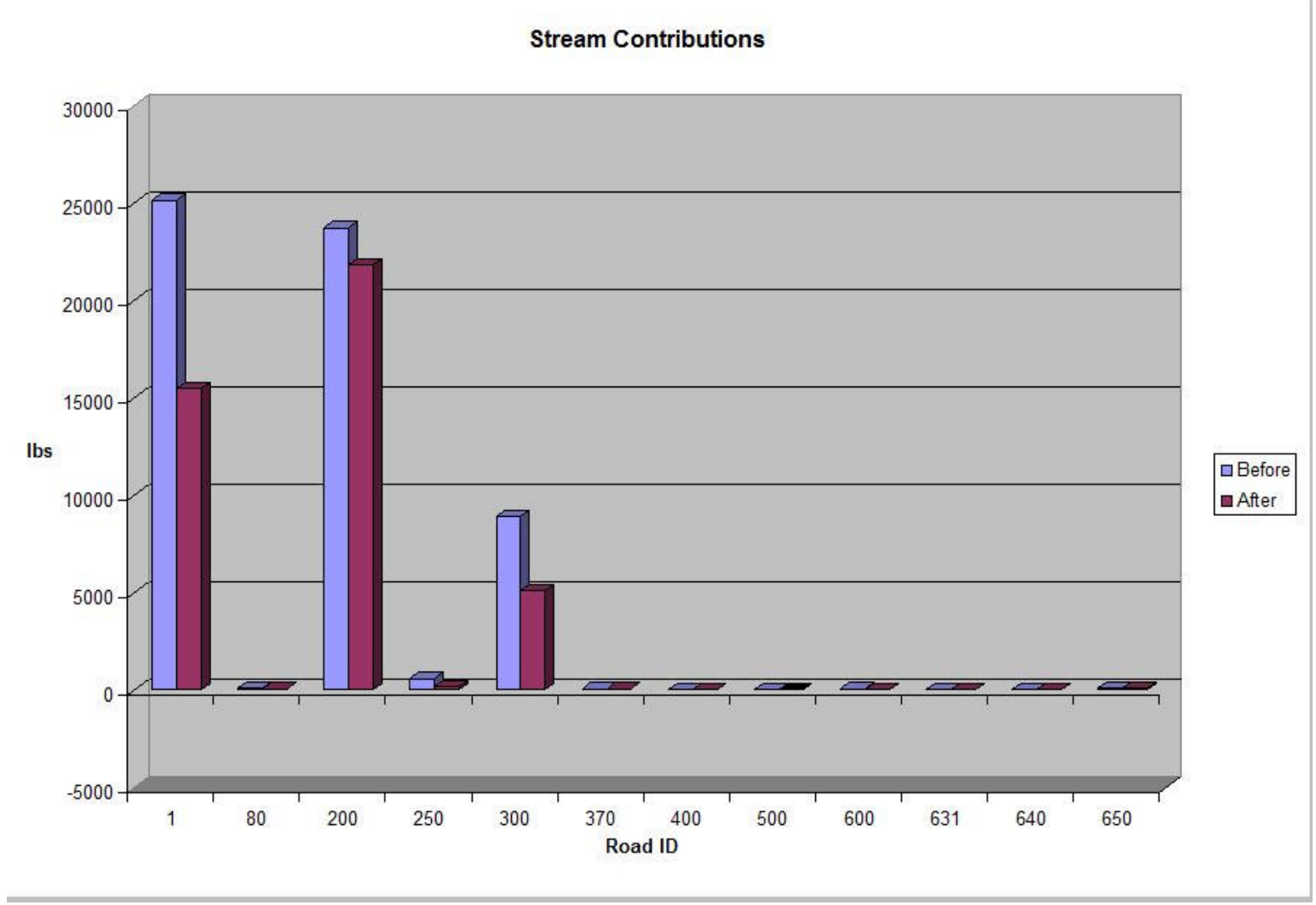

Figure 14. Stream Contributions Before and After Remediation.

The remediation process included the installation of 110 rolling dips, but only 40 of those affected sediment delivery to a stream. The findings suggested that total sediment delivery was reduced by $26 \%$, totaling a reduction of 15,884 pounds per year. The results also showed large fluctuations in the data, because the data is dependent on the road segment and its proximity to a stream (Table 1).

In a few instances, the results showed an increased contribution to stream systems. Further analysis suggested that this was due to an increased fillslope gradient at the point where water was diverted from the road. This factor transported erosion at a faster rate, allowing it move further within the system. 
Another possible reason was that water was diverted in closer proximity to an NHD line. In any case, the increased contribution to streams proved insignificant and accounted for less than $0.02 \%$ of total sediment delivery to the stream.

Table 1. Reduced Stream Contributions

\begin{tabular}{|c|c|c|c|}
\hline Road ID & $\begin{array}{c}\text { Reduced Sediment to } \\
\text { the Stream System (Ibs) }\end{array}$ & $\begin{array}{c}\text { Reduced Sediment to } \\
\text { the Stream System (\%) }\end{array}$ & $\begin{array}{c}\text { No. of Rolling } \\
\text { Dips }\end{array}$ \\
\hline $1-60$ & 9711.68 & 39 & 3 \\
\hline $80-99$ & 32.77 & 68 & 6 \\
\hline $200-236$ & $1,901.86$ & 9 & 2 \\
\hline $250-286$ & 404.55 & 70 & 8 \\
\hline $300-325$ & $3,818.74$ & 43 & 5 \\
\hline $370-380$ & +1.37 & +2 & 6 \\
\hline $400-408$ & 0 & 0 & 0 \\
\hline $500-536$ & +3.49 & +100 & 1 \\
\hline $600-630$ & 19.74 & 52 & 9 \\
\hline $631-634$ & 0 & 0 & 0 \\
\hline $640-644$ & 0 & 0 & 0 \\
\hline $650-678$ & 0 & 0 & 0 \\
\hline Totals & $\mathbf{1 5 , 8 8 4 . 4 8}$ & $\mathbf{2 7}$ & $\mathbf{4 0}$ \\
\hline
\end{tabular}

Figure 15 displays priority areas, based on their proximity to streams and the amount of erosion potential. This determination allowed stakeholders to target specific points where remediation efforts would have the largest impact on streams. 


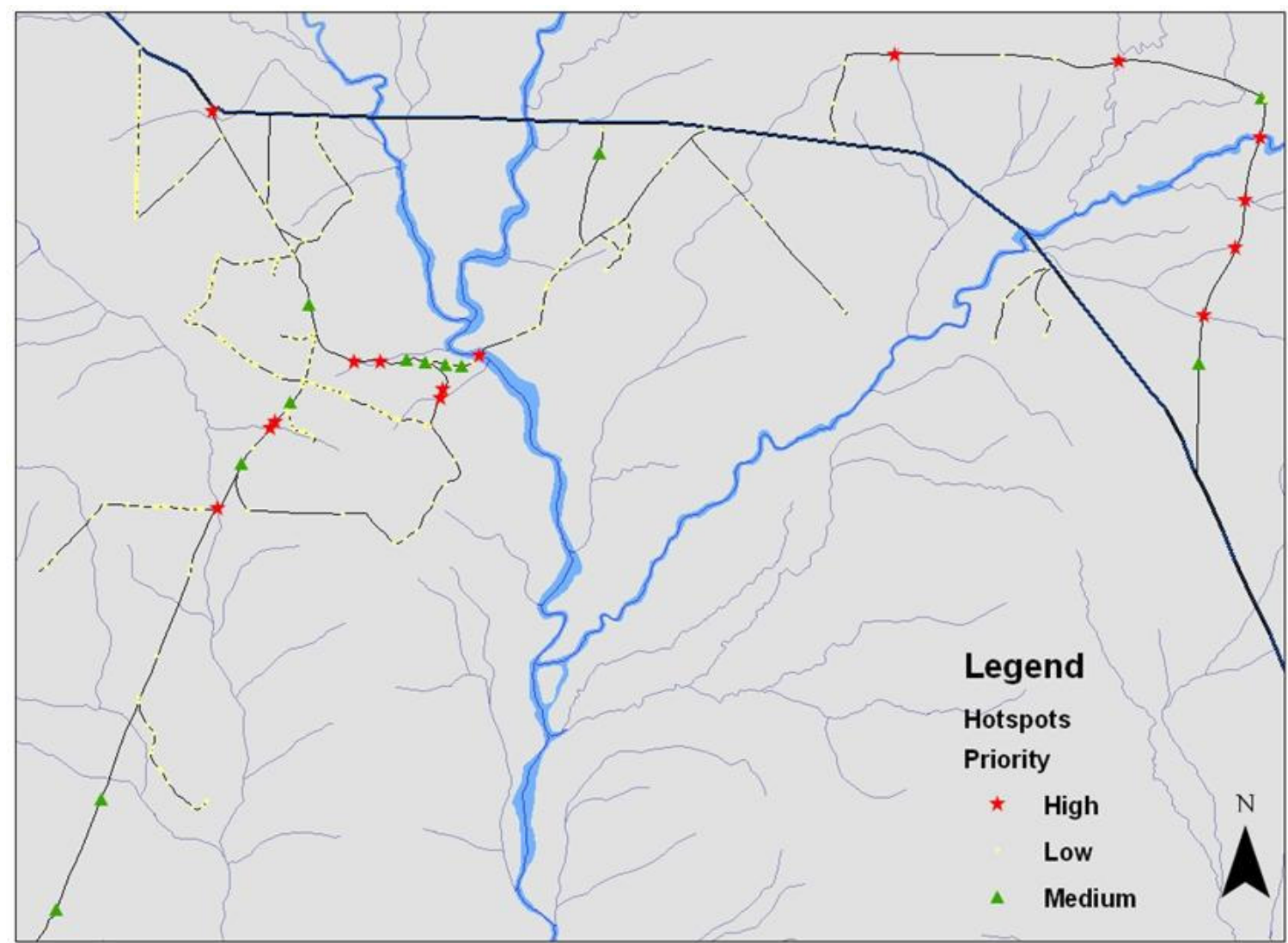

Figure 15. Priority areas based on proximity to streams.

\section{Case Study: A Before-and-After Analysis of Mitigation Efforts}

The initial analysis centered around 12 roads where remediation had been completed (Figure 16). Remediation involved the installation of rolling dips with an adjacent water bar. The structures were created to divert water from the road, thereby preventing water from continuing downhill and causing further erosion. The remediation project involved installation of 110 rolling dips along a total of $16.65 \mathrm{mi}$ of road. 


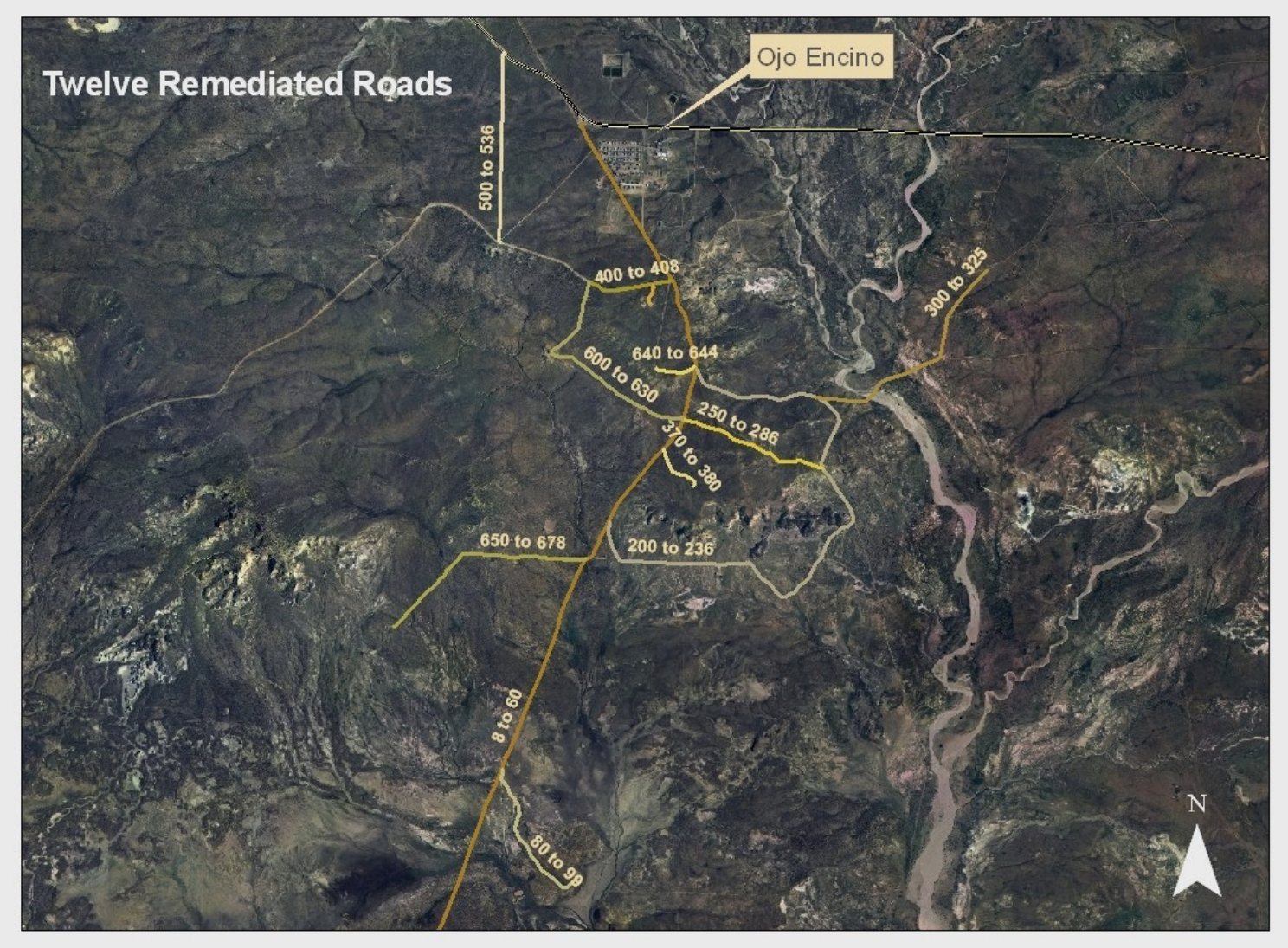

Figure 16. Twelve remediated roads in the study area.

Local officials, familiar with of the area, installed and placed rolling dips along roads with observed erosion problems. Each rolling dip was designed to divert water to an adjacent water bar (Figure 17). To differentiate them from preexisting road conditions, rolling dips were noted as both high points and delivery points. To assist in later analysis, the data dictionary was programmed with a field titled "work" wherein each rolling dip was given a letter from A-Z. 


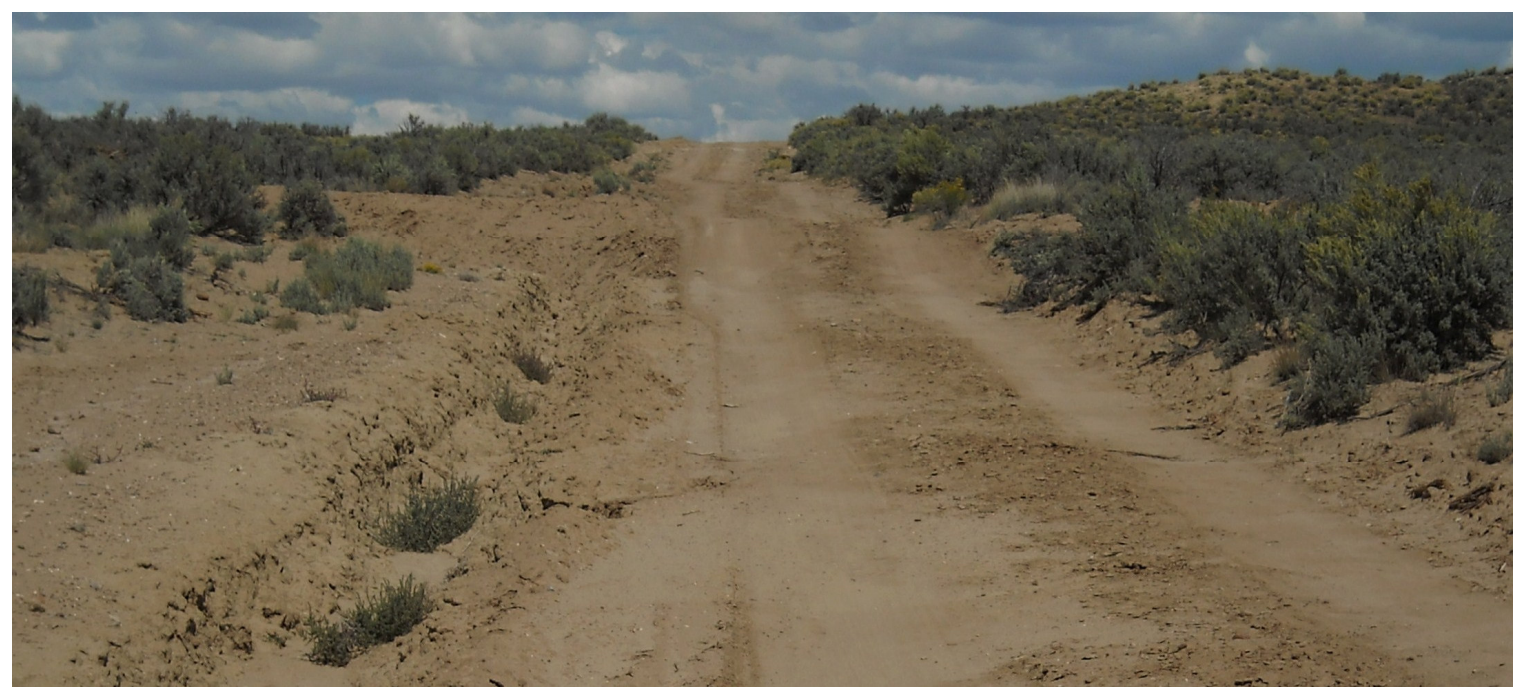

Figure 17. Example of rolling dip and water bar remediation efforts.

\section{Case Study Methodology}

The data were run through WEPP in two ways. First, the data was imported into WEPP: Road Batch to compute the as-built scenario, which takes into account the rolling dips. Using Excel, data were then manipulated to replicate conditions that existed before the structures were built. Table 1

illustrates the before-and-after conditions. Data was collected with the rolling dips in place so data was altered to re-create the conditions before remediation. The road design, surface, and traffic level remained the same. The length is the sum of the road lengths from high point to delivery point, to mimic the distance traveled before rolling dips were installed. To avoid small variations in slope, road gradient was measured in the field from the high point to the delivery point. The parameters for the fillsope length and gradient were the same as the natural delivery point. The before conditions were then run through WEPP. The results could then identify erosion potential before and after remediation and account for any reduced erosion. 
Table 2. Data from Excel used to Match Original Conditions.

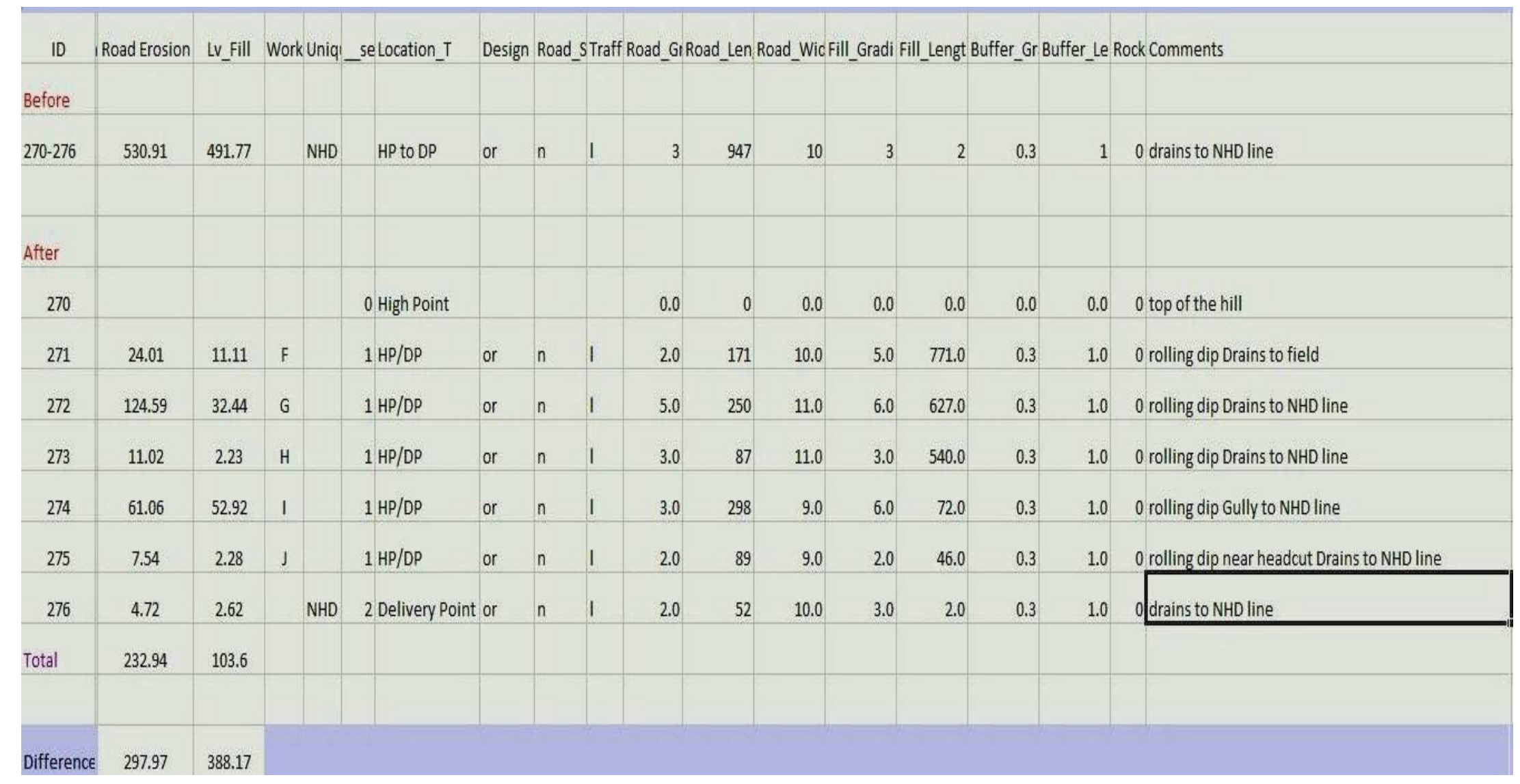




\section{Case Study Results}

The results showed significantly less erosion in almost all cases (Table 3). Data suggested that an average of $48 \%$ of road erosion was reduced, while $51 \%$ was prevented from passing over the adjacent landscape, where it could contribute to a field or stream system.

Table 3. Percentage of Sediment Reduction.

\begin{tabular}{|c|c|c|}
\hline Road ID & $\begin{array}{c}\text { Sediment Reduction from } \\
\text { the Road } \\
(\%)\end{array}$ & $\begin{array}{c}\text { Sediment Reduction to the } \\
\text { Landscape } \\
(\%)\end{array}$ \\
\hline $1-60$ & 38 & 67 \\
\hline $80-99$ & 42 & 43 \\
\hline $200-236$ & 57 & 63 \\
\hline $250-286$ & 39 & 57 \\
\hline $300-325$ & 39 & 48 \\
\hline $370-380$ & 49 & 17 \\
\hline $400-408$ & 47 & 23 \\
\hline $500-536$ & 57 & 63 \\
\hline $600-630$ & 34 & 46 \\
\hline $631-634$ & 45 & +54 \\
\hline $640-644$ & 79 & 53 \\
\hline $650-678$ & 48 & $\mathbf{5 1}$ \\
\hline Totals & 48 & \\
\hline
\end{tabular}

Study findings suggested that installation of rolling dips had a dramatic effect on the rate of road erosion. On an annual basis, road erosion was reduced from 76,005 pounds per year to 41,419 pounds per year. When these results are replicated yearly, the overall benefit could be enormous. However, it is important 
to note that the structures themselves are capable of eroding, thereby requiring on-going maintenance.

Results also indicated that a large amount of sediment could be abated by the use of rolling dips throughout the road network (Figure 18). The reduced erosion was most-likely due to the shorter road lengths created by using the rolling dip technique, which eliminated the volume of runoff as well as the water velocity gained from water traveling long distances.

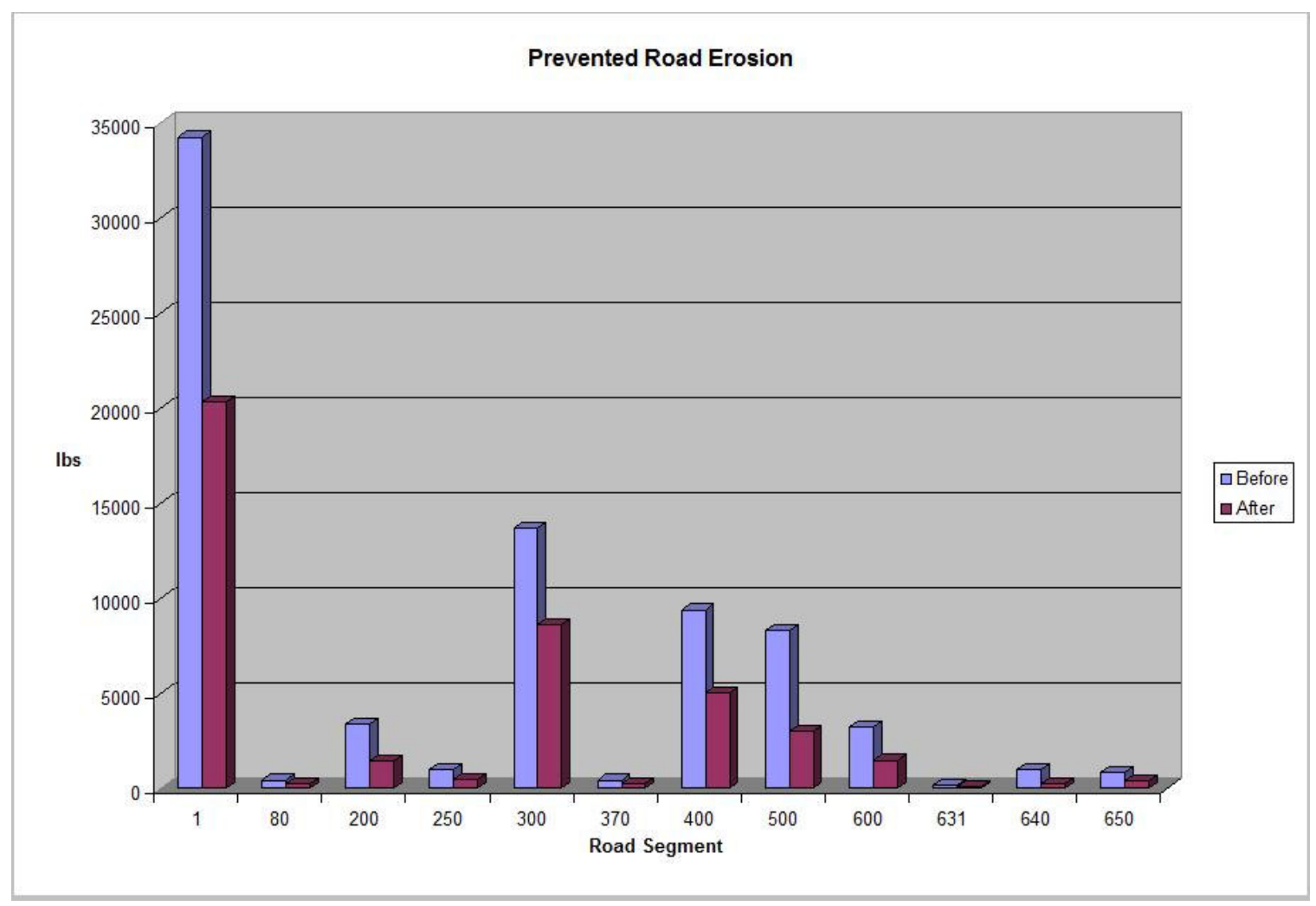

Figure 18. Reduced road erosion for remediated roads.

There was no evidence to support that increasing the number of rolling dips on each segment of road would continue to provide increased benefits; 
Table 4 illustrates this premise. Increased benefits appeared to be more a matter of placement, in areas where higher gradients and longer lengths are observed.

Table 4. Reduced Erosion and the Number of Rolling Dips.

\begin{tabular}{|c|c|c|c|c|}
\hline Road ID & $\begin{array}{c}\text { Sediment } \\
\text { Reduction from the } \\
\text { Road (Ibs) }\end{array}$ & $\begin{array}{c}\text { Sediment } \\
\text { Reduction to the } \\
\text { Landscape (Ibs) }\end{array}$ & $\begin{array}{c}\text { Number of } \\
\text { Rolling } \\
\text { Dips }\end{array}$ & $\begin{array}{c}\text { Length of } \\
\text { the Road } \\
\text { (miles) }\end{array}$ \\
\hline $1-60$ & $13,940.18$ & $18,273.54$ & 8 & 5.7 \\
\hline $80-99$ & 213.39 & 37.38 & 8 & 0.83 \\
\hline $200-236$ & $1,937.84$ & $1,901.86$ & 2 & 3.13 \\
\hline $250-286$ & 488.31 & 441.52 & 12 & 0.81 \\
\hline $300-325$ & $5,088.16$ & $4,017.80$ & 10 & 1.25 \\
\hline $370-380$ & 203.62 & +1.37 & 7 & 0.30 \\
\hline $400-408$ & $4,360.38$ & 533.92 & 3 & 0.45 \\
\hline $500-536$ & $4,290.20$ & 350.46 & 27 & 1 \\
\hline $600-630$ & $1,768.24$ & $1,488.25$ & 19 & 1.4 \\
\hline $631-634$ & 63.75 & +13.47 & 2 & 0.2 \\
\hline $640-644$ & 78.34 & 75.29 & 3 & 0.33 \\
\hline $650-678$ & 452.58 & 113.33 & 9 & 1.25 \\
\hline
\end{tabular}

A significant part of the remediation included closure and restoration of marginal roads. Roads that were closed were determined by local officials, based on their needs. For example, a residence with more than one access road was evaluated and, if possible, alternate roads were closed. Closed roads were documented as part of the analysis and digitized for use in GIS, although closed roads were not studied for potential erosion. A total of 49 roads, totaling 25.57 miles, are now closed. Once vegetation was established on a road, the erosion potential was dramatically reduced (Figure 19). It is likely that additional road 
closures will have a larger impact on sedimentation than the remediation of existing roads.

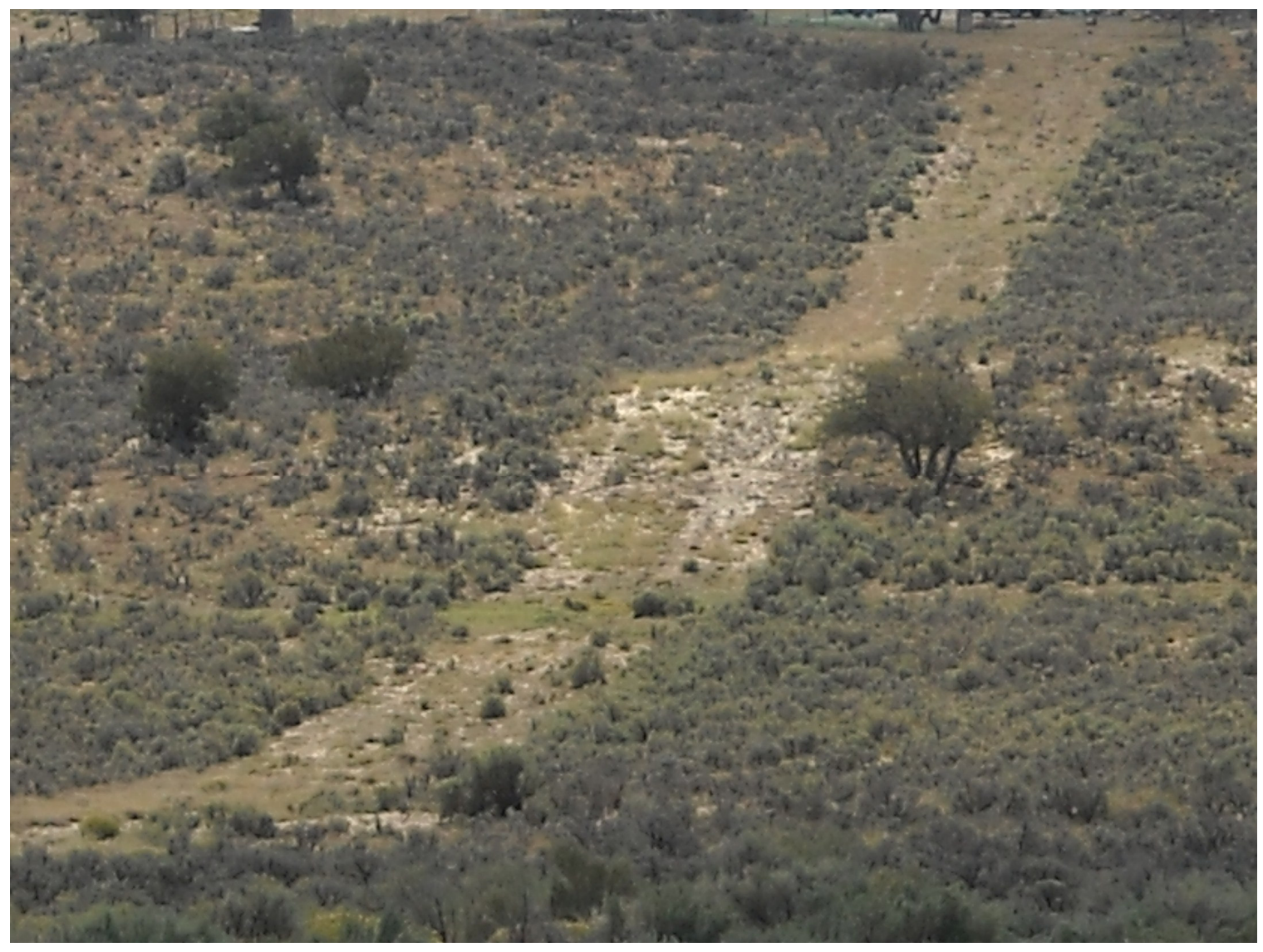

Figure 19. New vegetation on a closed road.

\section{RECOMMENDATIONS}

The Upper Torreon Wash is a high-erosion area. Additional field studies and work are required to address sediment arising from undocumented roads in the area. Characteristics that have the greatest impact on road erosion are the road length and gradient; length is a primary factor in determining the distance sediment will move once it leaves the road (Grace and Elliot, 2008). 
Results from this study indicate that road design plays an important role in sediment production and delivery. Road design within the study area consists of crowned roads with two ditches and outsloped rutted status. The crowned roads tend to be wide and experience high traffic. These roads are maintained and regularly bladed by the BIA. The outsloped rutted roads tend to occur on private property and the design characteristics resulted from vehicular use rather than from formal design and regular maintenance. Therefore, the data were separated to look at the effects from the two road designs.

Table 7. Road Design.

\begin{tabular}{|c|c|c|c|c|c|}
\hline $\begin{array}{l}\text { No. } \\
\text { Roads }\end{array}$ & $\begin{array}{l}\text { No. } \\
\text { Remediated } \\
\text { Roads }\end{array}$ & $\begin{array}{l}\text { Road } \\
\text { Erosion } \\
\text { (lbs) }\end{array}$ & $\begin{array}{c}\% \text { of } \\
\text { Total } \\
\text { Road } \\
\text { Erosion }\end{array}$ & $\begin{array}{c}\text { Sediment } \\
\text { Routed Over } \\
\text { the Landscape }\end{array}$ & $\begin{array}{l}\% \text { of Sediment } \\
\text { Routed Over } \\
\text { the Landscape }\end{array}$ \\
\hline \multicolumn{6}{|c|}{ Crowned with Two Ditches } \\
\hline 9 & 4 & 368,519 & 95 & 99,727 & 96 \\
\hline \multicolumn{6}{|c|}{ Outsloped Rutted } \\
\hline 13 & 8 & 18,409 & 5 & 4,265 & 4 \\
\hline
\end{tabular}

The results indicate that $95 \%$ of total road-prism erosion is coming from the crowned roads with two ditches. Future work could provide the largest benefit by remediating roads with this design.

\section{LIMITATIONS}

The advantage of the WEPP interface is that it is easy to use; the downside is that it lacks flexibility. For example, soil choices are limited to four 
main types that may not suit the conditions found in the area. The soil type is therefore not an exact match, but rather a 'best fit' scenario (See Appendix A).

Another limitation to WEPP is the size allowed for road length segments, which is limited to $1,000 \mathrm{ft}$. To overcome this particular problem, road lengths longer than 1,000 feet had to be divided into smaller segments and run through the WEPP interface, and then combined. Therefore, the data results are most likely artificially low.

The NHD lines provided a standard for the stream network, but it was limited in scope because the NHD lines do not account for stream segments shorter than 1 mile. The landscape contains small, concentrated flow paths that are capable of sediment transport and delivery. It is likely that smaller stream channels are contributing to the sediment transport and delivery, but were not considered in this analysis because of their shorter length.

The topography as a whole was also not accounted for in this analysis. Runoff from hillsides and adjacent landscapes may be adding additional sediment to the road network, a factor that can intensify the effects of erosion. In order to adequately account for the terrain, a different methodology may need to be utilized. The scope of this analysis was limited to the road network itself, and future funding could provide an additional level of complexity to the current data. Other forms of data should be also be considered, including the digital elevation models used in GIS. This would eliminate some of the need for manual data collection. 
The accuracy of WEPP is difficult to determine without control studies. However, the data do provide an impression of erosion in the area, although the significance is better represented by percentage of reduction than by attempting to predict an exact amount of road erosion.

\section{CONCLUSIONS}

This analysis provides a framework for future remediation efforts. The data give an overview of sediment production and provide the tools required to make future decisions based on specific needs. The remediation can target drainage points which impact the infrastructure, focus on erosion rates per foot, concentrate on sediment delivery to streams, or simply look at the road design.

When viewing the larger picture, overall road erosion totaled 386,928 pounds per year and sediment routed over the landscape totaled 103,992 pounds per year. With remediation activities, the overall totals show that $9 \%$ of road prism erosion was prevented, and $26 \%$ of sediment was prevented from entering the landscape. The general intent of remediation was to reduce erosion, and it has proven to be successful. 


\section{Appendix A}

\begin{tabular}{|c|c|c|c|c|c|c|}
\hline \multicolumn{7}{|c|}{ Road texture } \\
\hline & $\begin{array}{l}\text { Clay } \\
\text { Loam }\end{array}$ & $\begin{array}{c}\text { Silt } \\
\text { Loam }\end{array}$ & $\begin{array}{l}\text { Sandy } \\
\text { Loam }\end{array}$ & Loam & Actual * & \\
\hline $\begin{array}{l}\text { Albedo of the bare dry } \\
\text { surface soil }\end{array}$ & 0.6 & 0.6 & 0.6 & 0.6 & & Units \\
\hline $\begin{array}{l}\text { Initial saturation level of the } \\
\text { soil profile porosity }\end{array}$ & 0.5 & 0.5 & 0.5 & 0.5 & & $\mathrm{~m} / \mathrm{m}$ \\
\hline $\begin{array}{l}\text { Baseline interrill erodibility } \\
\text { parameter }\left(\boldsymbol{k}_{i}\right)\end{array}$ & $1.50 \mathrm{E}+06$ & $2.00 \mathrm{E}+06$ & $2.00 \mathrm{E}+06$ & $2.00 \mathrm{E}+06$ & & $\mathrm{~kg}^{*} \mathrm{~s} / \mathrm{m}^{4}$ \\
\hline $\begin{array}{l}\text { Baseline rill erodibility } \\
\text { parameter }\left(k_{r}\right)\end{array}$ & 0.0002 & 0.0003 & 0.0004 & 0.0003 & & $\mathrm{~s} / \mathrm{m}$ \\
\hline $\begin{array}{l}\text { Baseline critical shear } \\
\text { parameter }\end{array}$ & 10 & 10 & 10 & 10 & & $\mathrm{~N} / \mathrm{m}^{2}$ \\
\hline $\begin{array}{l}\text { Effective hydraulic } \\
\text { conductivity of surface soil }\end{array}$ & 0.1 & 0.27 & 3.8 & 0.3 & 0.28 & $\mathrm{~mm} / \mathrm{h}$ \\
\hline & & & & \multicolumn{3}{|c|}{ layer 1} \\
\hline $\begin{array}{l}\text { Depth from soil surface to } \\
\text { bottom of soil layer }\end{array}$ & 200 & 200 & 200 & 200 & 200 & $\mathrm{~mm}$ \\
\hline Percentage of sand & 30 & 30 & 60 & 40 & $18-70.4$ & $\%$ \\
\hline Percentage of clay & 30 & 15 & 5 & 20 & $15-31$ & $\%$ \\
\hline $\begin{array}{l}\text { Percentage of organic matter } \\
\text { (by volume) }\end{array}$ & 0.01 & 0.01 & 0.01 & 0.01 & $.25-.27$ & $\%$ \\
\hline Cation exchange capacity & 24 & 12 & 4 & 16 & 15 & $\begin{array}{l}\text { meq per } \\
100 \mathrm{~g} \text { of }\end{array}$ \\
\hline $\begin{array}{l}\text { Percentage of rock fragments } \\
\text { (by volume) }\end{array}$ & 0 & 0 & 0 & 0 & & $\%$ \\
\hline
\end{tabular}




\begin{tabular}{|c|c|c|c|c|c|c|}
\hline \multicolumn{7}{|c|}{ Fill texture: loam } \\
\hline $\begin{array}{l}\text { Albedo of the bare dry } \\
\text { surface soil }\end{array}$ & 0.12 & 0.12 & 0.12 & 0.12 & & \\
\hline $\begin{array}{l}\text { Initial saturation level of the } \\
\text { soil profile porosity }\end{array}$ & 0.45 & 0.45 & 0.45 & 0.45 & & $\mathrm{~m} / \mathrm{m}$ \\
\hline $\begin{array}{l}\text { Baseline interrill erodibility } \\
\text { parameter }\left(k_{i}\right)\end{array}$ & $1.50 \mathrm{E}+06$ & $2.00 \mathrm{E}+06$ & $2.00 \mathrm{E}+06$ & $2.00 \mathrm{E}+06$ & & $\mathrm{~kg}^{*} \mathrm{~s} / \mathrm{m}^{4}$ \\
\hline $\begin{array}{l}\text { Baseline rill erodibility } \\
\text { parameter }\left(k_{r}\right)\end{array}$ & 0.0002 & 0.0003 & 0.0004 & 0.0003 & & $\mathrm{~s} / \mathrm{m}$ \\
\hline $\begin{array}{l}\text { Baseline critical shear } \\
\text { parameter }\end{array}$ & 2 & 2 & 2 & 2 & & $\mathrm{~N} / \mathrm{m}^{2}$ \\
\hline $\begin{array}{l}\text { Effective hydraulic } \\
\text { conductivity of surface soil }\end{array}$ & 6.3 & 8.9 & 12.5 & 10 & 0.28 & $\mathrm{~mm} / \mathrm{h}$ \\
\hline & & & & \multicolumn{3}{|c|}{ layer 1} \\
\hline $\begin{array}{l}\text { Depth from soil surface to } \\
\text { bottom of soil layer }\end{array}$ & 300 & 300 & 300 & 300 & 300 & $\mathrm{~mm}$ \\
\hline Percentage of sand & 30 & 30 & 60 & 40 & $18-70.4$ & $\%$ \\
\hline Percentage of clay & 30 & 15 & 5 & 20 & $15-31$ & $\%$ \\
\hline $\begin{array}{l}\text { Percentage of organic matter } \\
\text { (by volume) }\end{array}$ & 4 & 4 & 4 & 4 & $25-.27$ & $\%$ \\
\hline Cation exchange capacity & 26 & 13 & 4 & 17 & 15 & $\begin{array}{l}100 \mathrm{~g} \text { of } \\
\text { soil }\end{array}$ \\
\hline $\begin{array}{l}\text { Percentage of rock fragments } \\
\text { (by volume) }\end{array}$ & 0 & 0 & 0 & 0 & & $\%$ \\
\hline
\end{tabular}




\section{REFERENCES}

Aby, S., A. Gellis, and M. Pavich, 2004. The Rio Puerco Arroyo Cycle and History of Landscape Changes. Rio Puerco Online; accessed 5/21/08 at http://geochange.er.usgs.gov/sw/impacts/geology/puerco1/

Alberts, E.E., M.A. Nearing, M.A. Weltz, L.M. Risse, F.B. Pierson, X.C. Zhang, J.M. Laften, and J.R. Simanton, 1995. Soil Component, Chapter 7: USDA Water Erosion Prediction Project Hillslope Profile and Watershed Model Documentation NSERL Report No. 10. USDA-ARS-MWA, West Lafayette, IN. July 1995.

Brooks, E.S., J. Boll, W.J. Elliot, and T. Dechert, 2006. Global Positioning System/GIS-Based Approach for Modeling Erosion from Large Road Networks. Journal of Hydrologic Engineering 11(5):418-426.

Elliot, W.J., D.E. Hall, and D.L. Scheele, 1999. WEPP Interface for Predicting Forest Road Runoff, Erosion, and Sediment Delivery; Technical Documentation. USDA Forest Service Rocky Mountain Research Station and San Dimas Technology and Development Center.

Elliot, W.J., 2004. WEPP Internet Interfaces for Forest Erosion Prediction. Journal of the American Water Resources Association 40(2):299-306.

Flanagan, D.C., C.S. Renschler, and T.A. Cochrane, 2000. Application of the WEPP Model with Digital Geographic Information GIS/EM4 No. 149. 4th International Conference on Integrating GIS and Environmental Modeling, Alberta, Canada. September 2-8, 2000.

Foster, G.R., D.C. Flanagan, M.A. Nearing, L.J. Lane, L.M. Risse, and S.C. Finkner, 1995. Hillslope Erosion Component, Chapter 11: USDA Water Erosion Prediction Project Hillslope Profile and Watershed Model Documentation, NSERL Report No. 10. USDA-ARS-MWA, West Lafayette, IN. July 1995.

Gellis, A., 2006. History of Streamflow and Suspended Sediment Collection in the Rio Puerco Basin, New Mexico. USGS webpage accessed 4/18/08 at http://esp.cr.usgs.gov/rio_puerco/erosion/streamflow.html

Grace, J.M. III, and W.J. Elliot, 2008. Determining Soil Erosion from Roads in the Coastal Plain of Alabama. In Proc. Environmental Connection 08, Conference 39, Orlando, FL. International Erosion Control Association, Steamboat Springs, CO.

Laflen, J.M., D.C. Flanagan, and B.A. Engel, 2004. Soil Erosion and Sediment Yield Prediction Accuracy Using WEPP. Journal of the American Water Resource Association 40(2):289-297. 
Nicks, A.D., L.J. Lane, and G.A. Gander, 1995. Weather Generator, Chapter 2: USDA Water Erosion Prediction Project Hillslope Profile and Watershed Model Documentation NSERL Report No. 10. USDA-ARS-MWA, West Lafayette, IN. July 1995.

Rio Puerco Alliance, 2007. Targeted Watershed Restoration Initiative in Torreon Wash. Rio Puerco Alliance.

Rio Puerco Management Committee (RPMC). Accessed 4/18/08 at http://riopuerco.org/

Savabi, M.R., and J.R. Williams. 1995. Water balance and Percolation. Chapter 5, USDA-ARS National Soil Erosion Research Laboratory Publication. WEPP Model Documentation. pp. 14.

Savabi, M.R., R.A. Young, G.R. Benoit, J.M. Witte, and D.C. Flanagan, 1995. Winter Hydrology, Chapter 3: USDA Water Erosion Prediction Project Hillslope Profile and Watershed Model Documentation NSERL Report No. 10. USDA-ARS-MWA, West Lafayette, IN. July 1995.

Stone, J.J., L.J. Lane, E.D. Shirley, and M. Hernandez, 1995. Hillslope Surface Hydrology, Chapter 4: USDA Water Erosion Prediction Project Hillslope Profile and Watershed Model Documentation NSERL Report No. 10. USDA-ARS-MWA, West Lafayette, IN. July 1995.

USDA, 2008. General Description of Cligen Model and it's History. Accessed $7 / 19 / 08$ and 9/16/08 at http://topsoil.nserl.purdue.edu/nserlweb/weppmain/cligen/

USDA-NRCS, 2008. Web Soil Survey. Accessed 9/9/08 9/11/08 and 9/29/08 at http://websoilsurvey.nrcs.usda.gov/app/

USGS Earth Science Information Center, 1998. National Hydrography Dataset High-resolution: Personal GeoDatabase Feature Class. Accessed 9/23/08 at http://nhdgeo.usgs.gov/metadata/nhd_high.htm\#1

WEPP, 2008. User Summary. Accessed 5/15/08 at http://topsoil.nserl.purdue.edu/nserlweb/weppdoc/weppuserssummary.htm 